DIW BERLIN

Discussion

Papers

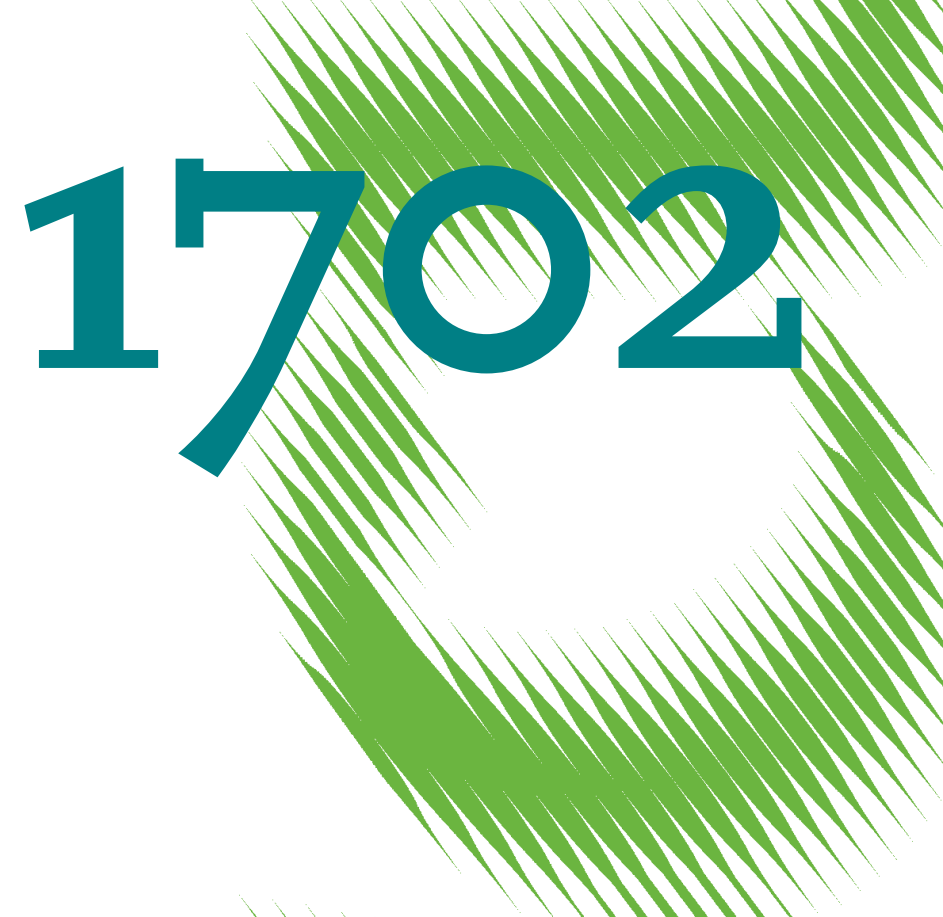

Financial Literacy and Financial

Behavior: Evidence from the

Emerging Asian Middle Class 
Opinions expressed in this paper are those of the author(s) and do not necessarily reflect views of the institute.

IMPRESSUM

(C) DIW Berlin, 2017

DIW Berlin

German Institute for Economic Research

Mohrenstr. 58

10117 Berlin

Tel. +49 (30) $89789-0$

Fax +49 (30) $89789-200$

http://www.diw.de

ISSN electronic edition 1619-4535

Papers can be downloaded free of charge from the DIW Berlin website:

http://www.diw.de/discussionpapers

Discussion Papers of DIW Berlin are indexed in RePEc and SSRN:

http://ideas.repec.org/s/diw/diwwpp.html

http://www.ssrn.com/link/DIW-Berlin-German-Inst-Econ-Res.html 


\title{
Financial Literacy and Financial Behavior: Evidence from the Emerging Asian Middle Class
}

\author{
Antonia Grohmann a,b \\ ${ }^{a}$ German Institute for Economic Research (DIW Berlin),Mohrenstr.11, 10117 Berlin, Germany \\ ${ }^{b}$ Leibniz University Hannover, Department of Economics, Hannover, Germany
}

This version: November, 2017

\begin{abstract}
This paper analyses financial literacy and financial behavior of middle class people living in an urban Asian economy. Other than most papers on financial literacy that focus on people in developed countries, we surveyed people living Bangkok. Using standard financial literacy questions, we find that financial literacy levels are largely comparable to industrialized countries, but understanding of more advanced financial concepts is lower. Similarly, savings accounts are held by most people, but more sophisticated products are a lot less common. We further show, in line with the literature, that higher financial literacy leads to improved financial decision making.
\end{abstract}

JEL classification: D14; G11; D91

Keywords: Financial literacy; Saving; Borrowing; Household finance 


\section{Introduction}

Good financial decision making is becoming increasingly important; the reasons behind this is a higher availability of more complex products and the heightened need to save for one's retirement. Whereas this is true for almost all people, these decisions are of particular importance for the middle classes in emerging economies, such as those in Asia. These economies are characterized by rapid growth, heavy structural changes and the emergence of a larger middle class (e.g. Kharas, 2010, Ravallion, 2010). Increasing incomes allow higher savings, and the number of ever more sophisticated financial products is constantly rising in these markets. Furthermore, longevity in combination with declining birth rates and an increase in social individualization increases the need for retirement planning. These changes have been most rapid in urban areas in many emerging markets, where at the same time a vast choice of sophisticated financial products is available to consumers. In order to address these challenges adequately and to use sophisticated products rationally, individuals need to have a certain financial understanding (Campbell, 2006). Hence, financial literacy is important for individuals to be able to tackle these challenges and it is therefore of particular importance for the middle class in emerging economies.

In this paper, we study the financial behavior and financial literacy of the urban middle class in Asia. The middle class has often been neglected in empirical studies, as papers on financial literacy have either looked at populations in industrialized countries (Lusardi and Mitchell, 2014) or focused on the poor living in developing countries (Xu and Zia, 2013). This is despite the important role that the middle class plays for growth and development (Ravallion, 2010, Banerjee and Duflo, 2008). One reason why the middle class in emerging markets has been argued as important for growth is that it has larger savings than the poor (Chun et al., 2017), mostly because the middle class tends to have stable employment (Banerjee and Duflo, 2008). In this light it is 
particularly important to study financial literacy and financial decision making of the middle class. Good financial decisions making by the middle class in emerging economies may have more far reaching consequences than financial decision making by the poor. Furthermore, policies that target the urban middle class would have to be very different to policies designed to target the poor parts of the population in emerging markets.

To study this population group, we fielded a survey in Bangkok, Thailand, collecting information of over 500 middle class people. This survey was designed especially to study the financial behavior and financial literacy in emerging Asia. Bangkok provides a good platform for this. Firstly, Thailand belongs to the group of emerging economies where a sizable middle class with significant financial needs and wealth has emerged, meeting the global middle class definition of Kharas (2010). ${ }^{1}$ This group is largely concentrated in the Bangkok area, where $23 \%$ of the Thai population lives, but which produces $44 \%$ of total GDP. Secondly, the financial sector grew quickly and the economy expanded significantly, meaning that the middle class had to adjust quickly to new financial products. Thirdly, the pension system in Thailand is small and undeveloped, implying that members of the middle class working in the private sector need to save for their retirement, without state support. Although sophisticated financial products are easily available to everyone in Bangkok, the question is whether they have sufficient financial literacy to take advantage of them.

Our sample is relatively homogenous with respect to age, income and education, making it well suited for studying non-sociodemographic factors such as financial literacy and their effects on financial behavior. To test the degree of financial literacy, we use standard items (Lusardi and Mitchell, 2007) and find that basic financial knowledge for middle class people in Bangkok is at

\footnotetext{
${ }^{\mathbf{1}}$ Precisely: average household income per person between $\$ 10$ and $\$ 100$ per day in purchasing power parity terms, measured in 2005 US dollars.
} 
the same level as that found in representative studies in developed countries. However, the results also indicate that our respondents struggle with more advanced financial knowledge, as only $24 \%$ can answer the standard stock market diversification question correctly. The relationships between socio-demographic variables and financial literacy are mostly those that are common in the literature: wealthier people with higher incomes are more financially literate and more educated people have higher financial literacy. Similarly, we find that younger people do better on all financial literacy questions. However, one results that is very unusual to the literature is that women do perform just as well as men on all questions. In most financial literacy studies, it is found that women have lower financial literacy than men (Lusardi and Mitchell, 2014, Grohmann et al. 2017).

We collect information on a large number of financial products and find that basic financial products are very wide spread in the Bangkok middle class. Everyone has a savings account and $34 \%$ of respondents have a credit card. At the same time, use of sophisticated financial products such as stocks and bonds is low ( $9 \%$ and $11 \%$ respectively), whereas bank accounts and deposits are the most common financial assets.

We further show that financial literacy explains a wide range of these savings as well as some borrowing decisions and so we demonstrate that financially literate individuals make better use of advanced financial products. However, the relationship between financial literacy and financial behavior suffers from potential endogeneity caused by potential measurement error or unobserved variable bias. Furthermore, reverse causality is also a potential problem; it is conceivable that holding advanced financial products such as stocks may provide some kind of financial literacy training. In order to address these problems, we use an instrumental variable approach. We collect several variables that refer to respondents' childhood. These variables have 
been used before by Grohmann et al. (2015) to study the childhood roots of financial literacy. They are particularly suited as instruments as they are correlated with financial literacy, but uncorrelated with financial decisions in adulthood. The analyses with instrumental variables confirm our earlier findings.

Our main contribution to the literature is showing the beneficial causal impact of financial literacy for a new sample representing the emerging middle class in Asia. As additional aspects, we consider a broader set of savings and borrowings decisions than typically covered in other studies on financial literacy. Furthermore, as we are using financial literacy questions that have been used in a large number of countries, we can easily compare our results to those from industrialized countries. We can further show that the results are robust, using instrumental variables regression.

The link between financial literacy and financial behavior has been looked at in a number of other studies. The literature of financial literacy first developed to study the link between financial literacy and retirement planning (Ameriks et al., 2003, Lusardi and Mitchell, 2007, Bucher-Koenen and Lusardi, 2011, van Rooij et al., 2011b). Apart from better retirement planning, financially literate individuals are more likely to invest in stocks (Christiansen et al., 2008, van Rooij et al., 2011a) and have more diverse portfolios (Guiso and Jappelli, 2008, Abreu and Mendes, 2010). Regarding borrowing decisions, financially literate people have lower cost debt and are more likely to be aware of their optimal debt level (Lusardi and Tufano, 2015, Stango and Zinman, 2009). They have less high-cost consumer credit (Disney and Gathergood, 2013) and fewer problems with repaying credit card debt (Gathergood, 2012).

Financial literacy is also an important topic for developing countries: we refer to Xu and Zia (2013) for a review of the literature. Levels of financial literacy in emerging markets are lower 
than in industrialized countries (Hastings and Tejada-Ashton, 2008, Cole et al., 2011, Klapper and Panos, 2011, Beckmann, 2013), especially in rural areas. At the same time, studies in developing countries confirm that better financial literacy is positively related to retirement planning (Klapper and Panos, 2011), to greater participation in financial markets, to greater use of formal sources of borrowing (Klapper et al., 2013), to higher voluntary savings (Landerretche and Martinez, 2013) and to better diversification (Beckmann, 2013).

A more recent strand of the literature focuses on the effect of financial literacy trainings on financial decision making. Many of these studies are based on randomized control trails, studying poor people in developing countries. Results of these studies show that the effect of financial literacy training is small (Fernandes et al, 2014), but training is more effective in improving savings behaviors than borrowing behaviors (Kaiser and Menkhoff, 2017).

The evidence on financial literacy is limited to population-wide studies or poorer areas in developing countries. Within a single developing country large differences tend to exist in wealth and access to finance, ranging from the rural poor without bank accounts to urban workers investing in mutual funds. Clearly, both groups need to be targeted by separate policies. While several studies cover financial literacy in poorer rural areas, research focusing on the middle class in emerging economies is lacking, a gap that this paper aims to fill.

We proceeds as follows from here on: section 2 described data collection and gives descriptive statistics, section 3 gives results, robustness checks are done in section 4 and section 5 concludes. 


\section{Data description}

\subsection{The financial-economic background of Thailand and Bangkok}

With our financial literacy survey we specifically target the middle class in Bangkok, Thailand. Over the last 50 years Thailand has rapidly developed from a relatively poor agricultural society with GDP per capita of 101 USD in 1965 to an "upper-middle income" economy with GDP per capita of 5,480 USD in 2012 (in current USD, source: World Bank), the year of our survey. ${ }^{2}$ Regional disparity is hiding behind this remarkable success story of economic transformation and development. Thailand has a population of 66 million people as of 2012, of which 15 million (23\%) live in the capital city Bangkok and its direct vicinity. ${ }^{3}$ Bangkok is the administrative, economic and financial center of the country, producing $44 \%$ of Thailand's GDP. As a result, GDP per capita in Bangkok is twice the national average, similar to Greece and the Czech Republic (corrected for purchasing power). ${ }^{4}$

Consumer finance services in Bangkok are modern and well developed, including a dense network of banks and ATM's, providing access to savings accounts, time deposits, investment funds (stock, bonds), credit cards, consumer loans and home mortgages. A special feature in Bangkok are gold shops, present in most neighborhoods, where gold bars and jewelry are traded. Insurance products are available at bank branches and also sold through a large direct sales network. In addition, offices of brokers are widespread, providing direct access to the local stock and bond markets. Like in developed countries, online banking and online brokerage services are also available.

\footnotetext{
${ }^{2}$ Real GDP per capita grew from 437 USD in 1965 to 3,353 in 2012 (in constant 2005 USD, World Bank).

${ }^{3}$ Source: National Economic and Social Development Board (NESDB).

${ }^{4}$ When considering GDP per capita in nominal USD, without correcting for purchasing power effects, Bangkok's GDP per capita in 2012 (the year of the financial literacy survey) was similar to Turkey, Malaysia and Brazil.
} 
A worrisome recent trend is that the ratio of household debt to GDP was over $70 \%$ in 2015 , steeply rising from only 45\% in 2008 (source: Source: Institute of International Finance). This raises the question to what extent households fully understand the consequences of increasing debt service for their financial situation.

Similar to most developed countries, Thailand's has a rapidly ageing population, predicted to shrink from 2023 onwards. The number of retirees as a proportion of the population was 14\% in 2012 and is expected to increase to 32\% by 2050 (source: UN), above the global average. Although Thailand has a pension system with public and private pillars, both the coverage and the benefits are limited, due to a cap of public pensions and high levels of self or informally employed people. To counter the expected pension shortfall, the Thai government actively encourages individual retirement savings through tax-exempt equity funds and retirement funds, but this clearly requires some financial literacy.

\subsection{Defining the middle class}

Our objective is to study the financial literacy of people in Bangkok who are members of the rapidly growing global middle class in developing countries. Kharas (2010) and Kharas and Gertz (2010) define members of the global middle class as those who make between $\$ 10$ and $\$ 100$ per day in purchasing power parity terms, measured in 2005 dollars. This definition excludes those who are considered poor in the poorest advanced countries and those considered rich in the wealthiest advanced countries. Kharas (2010) chose this income range because the income 
elasticity of demand for consumer durables and financial services tends to be above one, indicating that consumption has moved beyond being just a necessity. ${ }^{5}$

\subsection{Data collection by survey}

The data necessary for this research is not available and thus had to be collected. Data collection took place in Bangkok over a ten day period in December 2012 in order to get useful responses from more than 500 persons. Interviews were conducted face to face by a Bangkok based market research company. The auther designed the questionnaire in collaboration with local experts and the market research company gave advice regarding its implementation. As next step we conducted a test run with individuals who have the same characteristics as the target group and the final version of the questionnaire was the basis for training the interviewers.

Survey participants were intercepted in public places throughout Bangkok and were chosen at random. The areas in which each team operated were decided on before the start of the survey; they consisted of six different main areas in Bangkok and 28 specific locations. Locations were chosen so that a balanced sample with respect to income, education and wealth would be collected. Hence data collection took place in business as well as residential areas of Bangkok. Interviewer teams consisted of three to four people, with one person acting as team leader. Each interviewer had previous experience conducting interviews and was trained on this specific questionnaire.

\footnotetext{
${ }^{5}$ Alternative definitions of the middle class in the literature include those who have escaped poverty by developing country standards, often defined as making more than $\$ 2$ per day in 2005 dollars (e.g., Ravallion, 2010). In our study we analyze savings and investment decisions, which requires higher income than merely being out of poverty. So called "relative" definitions of the middle class usually take an income range from $75 \%$ to $125 \%$ of the median income. However, such a definition is local by default, just singling out people who are close to the median income in a particular country.
} 
Rates of participation were fairly high with $85 \%$ of those approached willing to be part of the survey. Participants were made aware that the information would be used for academic research purposes only. Interviews took 20 to 30 minutes and participants were given a small present as a thank you for taking part.

Due to the potential difficulty caused by surveying using street intercepts, great care was taken to stratify the sample. Thus four pre-selection criteria were used (and respective questions asked) in order to determine suitability of each potential respondent. These four criteria are: age, income, financial responsibility and gender. (1) The individual's age was required to be between 18 and 60 years, with 60 being the mandatory retirement age, in order to target financially active respondents. (2) Participants had to earn at least 15,000 Baht per month (460 USD). The amount is equivalent to the starting salary for a recent graduate with a bachelor degree in Bangkok. ${ }^{6}$ (3) Interview subjects also had to be responsible for their own, or their household's, financial decisions. (4) Finally, regarding gender we aimed for a balanced group, considering the fact that women as well as men often have financial responsibility in the country. If individuals approached did not fulfill these requirements, interviews were discontinued after preliminary questions. Roughly 31\% of those approached failed initial screening, mostly due to incomes being too low.

The $\$ 10$ per day threshold for belonging to the global middle class is per capita, and thus depends on total household income and the number of household members. Our street interception survey design required a simpler and quicker criterion to help screen potential participants and for this reason we chose a personal income threshold of 15,000 Baht per month, which is 745 USD in constant 2005 dollars converted at PPP. A family of two earners making 15,000 Baht each can support three more household members (e.g., two children and one elderly parent), while still

\footnotetext{
${ }^{6}$ According to the Thai National Statistics Office (2011), 29\% of the regularly employed in Bangkok earn 15,000 Baht or more.
} 
making the $\$ 10$ per day threshold. In our sample of 530 respondents only 30 have average household income per person below the $\$ 10$ per day threshold (too poor), 8 are above the $\$ 100$ per day upper limit (too rich), and one person failed to provide information about household composition. Hence, we have a sample of 491 respondents from Bangkok meeting the global middle class definition of Kharas (2010).

\subsection{Description of socio-demographic variables}

Table 1 shows summary statistics of key socio-demographic variables for the middle class sample of 491 people as defined above. Both average individual and household income are higher than the Bangkok average. For example, mean individual income (see Table 1, Panel A) is 26,467 Baht per month (827 USD), while the average income of an employee in Bangkok was 16,961 Baht per month (530 USD) in 2011 according to the Thai National Statistics Office. The standard deviation of income is also high at 19,023 Baht, so there is substantial heterogeneity within the sample as well.

The average age is 34.5 years and most respondents have a higher educational degree. The highest educational attainment of $66 \%$ of our respondents is a bachelor degree, compared to $36 \%$ in the Bangkok labor force (National Statistics, 2011). As an explanation for the high education level in our sample (see Table 1, Panel B), we note that bachelor degrees have become a minimum requirement for white collar jobs in Thailand. As part of a push by the government to raise education levels, bachelor degree programs have grown rapidly.

The proportion of women in our sample is $47 \%$, close to the $49.6 \%$ population proportion among the labor force in Bangkok (National Statistics, 2011). Information on household composition is also collected, the average number of children is 0.8 and the number of adults per 
household is 2.9. These results indicate that many households include grown up offspring living with their parents, despite being part of the work force, which can be explained both by the familycentered Asian culture and the high costs of living.

Overall, our middle class sample is richer than the Bangkok average and also relatively highly educated. Indeed, the explicit purpose of the survey design was to exclude the poor and those just making enough to make ends meet, as both financial literacy and the demand for financial services in this group are substantially different due to lack of savings. ${ }^{7}$ For example, among the 30 people excluded from the sample for having low income, only one person owns a fixed deposit account (3.3\%) and four have a credit card (13\%), while among the 491 respondents included in our middle class sample $42 \%$ have a fixed deposit account and $34 \%$ have a credit card. Table A1 the Online Appendix provides statistics on the 30 respondents who are too poor to meet the middle class definition and the 8 that are too rich.

\subsection{Description of financial literacy}

Financial literacy measure. We measure financial literacy with the basic Lusardi and Mitchell score, first used by Lusardi and Mitchell in the 2004 US Health and Retirement survey (Lusardi and Mitchell, 2011), which have become standard in the literature. These questions test understanding of three key financial concepts: interest rates, inflation, and risk diversification. For the first question we make the slight adaption to a developing country as proposed by Cole et al. (2011). In line with the literature, we award one point for each question that is answered correctly.

In addition to these standard items, we also ask respondents to name foreign banks that operate in Thailand. By doing this, we try to expand the measure of financial literacy to include

\footnotetext{
${ }^{7}$ A financial literacy study of the Asian Development Bank (ADB, 2013) in Thailand explicitly targeted groups of urban poor living in Bangkok.
} 
institutional knowledge, which has been shown to be of importance for financial outcomes (Gustman et al., 2012, Carpena et al., 2011). There are about ten foreign banks operating in the retail market in Bangkok, but they are far less widespread than familiar local banks. For this reason we use being able to name foreign retail banks as a proxy for knowledge of financial institutions. The question is open-ended and there is no time limit on how long respondents can take to answer. Respondents are able to name up to four foreign banks. To construct our overall financial literacy measure, on top of the Lusardi and Mitchell literacy score, we award 0.25 points per foreign bank. This way we are giving the same weight to being able to name four foreign banks as we are giving to one of the other three questions. Thus, the overall financial literacy final score is in the range between zero and four. There are also other ways to measure financial literacy, but our results do not depend on the specific measure, as we demonstrate in the robustness section.

Financial literacy results. Regarding the Lusardi-Mitchell questions, the number of correct answers is fairly high for the first and second question. Knowledge of interest rates seems good, with $81 \%$ answering the first question correctly (Table 2, Panel A). Slightly fewer people seem to have a good grasp of inflation. Only $64 \%$ answered this question correctly, with $12 \%$ claiming that they don't know or refuse to answer. Most striking are the answers to the third question, which requires knowledge of the concept of portfolio diversification in the stock market context. Only $24 \%$ of respondents can answer this question correctly, with a high $52 \%$ answering I don't know/refuse to answer. It is not clear whether these poor results are due to a lack of knowledge about the stock market, or alternatively, because individuals do not grasp risk diversification. It is thus unsurprising that only $17.5 \%$ of the respondents answer all three questions correctly. Most respondents give two correct answers (43.0\%), while a small minority does not give any correct answers (9.8\%). 
As the benchmark questions have been used in many other countries, we can compare results across countries. It is most noticeable that the number of correct answers in Bangkok is not hugely different from those in developed countries for first two questions (Lusardi and Mitchell, 2014); however, results are considerably worse on the risk diversification question (see Xu and Zia, 2012). This indicates that while basic financial knowledge of interest rates and inflation in Bangkok is good, the resident middle class here lacks more advanced financial knowledge, despite wide availability of advanced financial products. At the same time, our Bangkok middle class residents do considerably better on all questions compared to general population surveys in developing countries (Xu and Zia, 2012, Lusardi and Mitchell, 2014). ${ }^{8}$

When it comes to naming foreign banks, respondents name between zero and four foreign banks, with only one person being able to name six foreign banks. To avoid an outlier in the financial literacy measure, this single observation was set back to four. The mean number of foreign banks mentioned is 2.25 (Table 2, Panel B), with 21.0\% being able to name four and 6.5\% being able to name none at all. Figure 1 shows the distribution of our new financial literacy measure that includes the name foreign banks score (scale: 0 to 4) in Panel B, and the standard Lusardi-Mitchell score (scale: 0 to 3 ) in Panel A. The new financial literacy measure is more evenly distributed, with a mean of 2.2 and median of 2.5 , while only $1.2 \%$ get a score of zero.

\subsection{Description of numeracy and risk attitude}

Financial literacy clearly involves a certain level of numeracy (mathematical ability), but pure knowledge of financial concepts is also necessary. In order to differentiate between financial literacy and numeracy, we ask four math-based questions, which correspond to four of the eight

\footnotetext{
${ }^{8}$ Interestingly, the low $24 \%$ proportion of correct answers on the stock market diversification question is comparable to urban sub-groups in Russia and Romania (Panos and Klapper, 2011, Beckmann, 2013).
} 
maths questions used by Cole et al. (2011). Respondents perform much better on these questions than on financial literacy, with the average number of correct answers being 3.6 (Table 3, Panels A and B), as opposed to 2.2 for the financial literacy items. These results indicate that the respondents are able to perform simple calculation tasks and poor performance on the financial literacy questions is mostly due to lack of financial knowledge.

In addition to this, a question on risk attitudes is included. The item is a qualitative measure of risk attitude, where respondents are required to place themselves on a scale from 0 to 10 , with 0 meaning "unwilling to take risk" and 10 meaning "fully prepared to take risk". This item has been applied before; see, for example, Dohmen et al. (2011) for Germany and Hardeweg et al. (2013) for Thailand. We turn this measure of risk tolerance into a measure for risk aversion by reversing the scale to a score between zero and one.

\subsection{Financial literacy by demographic group and correlates}

Correlations between our measure of financial literacy, numeracy and risk attitude are shown in Table 3, Panel C. Further, Table 4 shows financial literacy by gender, age, education, as well as by income groups and financial assets. We find that our data mainly show the expected patterns, both for our new measure of financial literacy as well as the Lusardi and Mitchell measure of financial literacy. Financial literacy is higher for respondents with higher education, higher income and higher financial assets. We refer to Table A2 in the Online Appendix for correlations between all main variables of this study.

Remarkable is the steep rise in the percentage of correct answers to the stock market diversification question as a function of income and financial assets, ranging from less than $20 \%$ correct in the lowest income and asset groups to more than $40 \%$ correct in the highest groups. The 
evidence supports the model of Jappelli and Padula (2013) where financial literacy and wealth are endogenous variables, jointly determined over the life-cycle.

We find one surprising result in Table 4, namely that the women in our sample do not have lower financial literacy than the men. In additional OLS regressions explaining financial literacy with respondent characteristics in the Online Appendix (Table A3), we find that demographic variables do not have the strongest relation with financial literacy, but rather numeracy, risk aversion and income, which is in line with findings by Meier and Sprenger (2013) and Fernandes et al. (2014).

\section{Results}

\subsection{Description of financial assets and debt}

In order to assess the link between financial literacy and financial behavior, data on the respondent's financial situation was collected. We asked for information on the amount of financial assets that respondents hold, along with what form financial assets are being held in. Results are shown in Table 5, Panel A.

Penetration of basic financial services is wide among the urban middle class; every respondent has a bank savings account. However, ownership of other financial assets is not as widely spread, as only $42 \%$ have a fixed deposit account and $8 \%$ of people hold gold to store wealth. More sophisticated financial assets are even less common than fixed deposits: only $11 \%$ of respondents own bonds or bond mutual funds, $8 \%$ hold stocks or an equity mutual fund, and $16 \%$ have a life insurance policy. In total only $53 \%$ of our respondents have other assets apart from a savings account, with the average number of other asset types held equal to 0.75 . Furthermore, $61 \%$ of the sample holds the largest proportion of their wealth in a savings account. 
Due to reservations about passing on financial information, the survey asks respondents to indicate their total amount of financial assets in five pre-defined categories, instead of asking for the exact amount. The level of assets in our sample is relatively low, with $49 \%$ claiming to hold less than 100,000 Baht (3,100 USD), 22\% have assets worth between 100,000 and 500,000 Baht (15,600 USD), and the remaining $8 \%$ hold assets in excess of 500,000 Baht. A further 20\% refuse to answer the question. The low amount of financial assets reported may be partially explained by a preference for investing in real estate and the relatively young age of our sample, apart from reservations about sharing this information.

Our findings for investments in financial assets are similar to results reported in Guiso and Sodini (2013) for the lowest wealth deciles in the U.S.: the majority of financial assets is held in cash, while participation in stock and bond markets is below $20 \%$. As wealth increases, financial asset holdings become more diversified and the weight of cash decreases. In our sample we find exactly the same pattern: Figure 1 shows stock and bond market participation as a function of the reported amount of financial assets. In the group with more than 500,000 Baht (15,600 USD) of financial assets stock market participation is $55 \%$, while $29 \%$ own bonds or bond funds. Hence, limited participation in financial markets among the emerging middle class may partially be explained by low wealth levels.

On the debt side, we ask for information on the total amount of debt and we collect information on the use of credit cards (see Panel B of Table 4), as credit cards can improve financial transactions considerably, but can also lead to problems if used irrationally. Levels of debt are fairly high, with $47 \%$ responding that they have an outstanding loan, are borrowing cash or paying for goods by installment. Respondents are reasonably open about their debts, with 77\% reporting an exact amount of debt, and 23\% not reporting the amount. Among respondents providing a 
positive debt amount, the average loan value is 256,300 Baht (8,010 USD), with a large standard deviation of 513,500 . For $20 \%$ of those reporting a positive debt amount, the loan amount is larger than their annual income.

Only $34 \%$ of the sample have a credit card, showing that credit card use is not yet widely spread among the Bangkok middle class, most likely due to lack of sufficient monthly income. ${ }^{9}$ Out of those with a credit card, $15 \%$ claim that they find it difficult to pay off their credit card debt every month. Further, 57\% do not know the interest rate charged by the credit card company, which is worrisome as credit card debt is one the most expensive sources of consumer finance.

\subsection{Financial literacy and saving decisions}

We here analyze the use of financial products beyond basic savings accounts. These indicators show that individuals are using the advanced financial system that is available to them. In detail, we rely on the following definitions of informed savings decisions:

(i) Virtually everyone in Bangkok's middle class holds a savings account. However, apart from convenience and safety, it is not a financial asset with attractive return features; in recent years the effective real rate of return (after inflation) on savings accounts has been negative. Thus holding assets other than a savings account serves as a most simple characteristic of informed savings behavior. The dependent variable is a dummy that is unity if the respondent holds an asset other than a savings account.

\footnotetext{
${ }^{9}$ We expect that some respondents fail to meet bank requirements for issuing a credit card, such as having sufficient regular income or liquid assets. A poll among 1,205 people aged 25 to 60-years in Greater Bangkok by Assumption University found that only 23.3\% of the respondents used credit cards (source: The Nation, 25 Sep 2013). In our sample, $43 \%$ of those in the group with self-reported financial assets between 100,000 and 500,000 Baht have a credit card, and $72 \%$ of those with high assets (more than 500,000 Baht).
} 
(ii) For the middle class in Thailand, fixed savings deposits are an advantageous product due to tax advantages and offering higher interest rates than savings accounts. Thus we analyze whether financial literacy is related to owning this product. In our analysis we use a dummy that is one if the respondent holds such a fixed deposit account, and zero otherwise.

(iii) Following the literature, another financial asset that offers positive expected long-term real returns but may require financial literacy, we analyze the ownership of stocks and stock mutual funds.

(iv) We finally analyze holding a product which we expect to be less attractive for the financially literate in the Thai context, having life insurance. The life insurance products offered in the retail market combine long-term savings contracts (e.g., for 5 or 10 years) with a life insurance policy. The interest rate offered is typically low, below government bond yields, but determining the effective rate of return requires high numeracy and financial skills. Still, regardless of its poor investment return, life insurance products may attract risk averse people.

Table 6 shows the regression results that explain these savings decisions. We find that the relationship between financial literacy and better financial behavior - as proxied by the dependent variables in specification (i) to (iv) - is mostly statistically significant and economically meaningful. Those that can score an additional point on the financial literacy measure are about 8 percentage points more likely to hold an asset other than a savings account at the mean, an increase of 15\%. Similarly, scoring an extra point increases the probability of having a fixed deposit account by about 6 percentage points $(+15 \%)$. Moreover, an extra financial literacy point reduces the likelihood of having life insurance by about 3 percentage points (-20\%).

Financial literacy explains all dependent variables except for stock market participation, which seems to be driven mainly by asset and income levels. It is remarkable that the effect of 
financial literacy is significant alongside the many control variables which cover the main aspects discussed in the literature, such as numeracy, education and income. Most notable is that education and financial literacy are significant in (almost) all columns of Table 6, in addition to controls for income and having low assets. This indicates to us that financial literacy is not synonymous with education. One does not guarantee the other, and specific knowledge of finance is needed in order to make good financial decisions. Numeracy is (weakly) significant for three out of five savings variables, with the expected sign. Thus, financial literacy contributes to informed savings decisions, even after controlling for the effect of numeracy and general education.

\subsection{Financial literacy and borrowing decisions}

Less researched than savings decisions is borrowing behavior. A problematic policy issue in many emerging economies, such as Thailand, is uninformed and excessive consumer credit. Credit cards can have advantages for certain transactions and promise easy access to credit, but also involve concerns of uninformed and excessive use of credit, for which we use two indicators:

(i) Consumers who do not know the (high) interest rate to be paid on credit card debt may underestimate the effective debt burden.

(ii) A full monthly repayment is rational as credit card debt is expensive, but is timely repayment a potential problem for consumers? Thus we ask people whether they regard monthly repayment as difficult.

Results for these two items are shown in columns 1 and 2 of Table 7. Financial literacy is negatively linked to both of these indicators. In particular, one extra point on the financial literacy scale ( 0 to 4 ) reduces the chance of not knowing the interest rate on credit card debt by 12.5 percentage points (-22\% relative to the mean), while it reduces the probability of finding it difficult to pay off credit card debt by 6 percentage points (-43\%). Moreover, our results show that financial 
literacy is the only variable that has significant explanatory power for these indicators, apart from gender and a dummy for high assets.

Another concern of policy makers refers to the level of debt for consumption purposes. Our data are arguably not perfect in this respect as some respondents do not give answers, or possibly do not always refer to consumption credit only. Nevertheless, with these qualifications, we examine three indicators of, possibly uninformed, borrowing decisions:

(iii) A large number of credit cards may signal a lack of spending control and excessive credit. We examine whether there is a link between the number of credit cards someone has and their level of financial literacy.

(iv) Another measure of uninformed or excessive borrowing is a high debt to income ratio, which is also a first indicator of credit bearing capacity.

Results for our indicators of borrowing do not show a direct relation with the degree of financial literacy. Rather, other variables better explain these borrowing indicators, such as age, income and having high assets. The non-linear relation between debt and age in columns (3) and (4) is a sign of income smoothing, as predicted by standard life-cycle models. In line with theory, younger people tend to borrow against future income, while older people pay off debt and draw down savings. Further, the importance of collateral and liquidity constraints for borrowing is apparent in column (3) and (4): respondents with high levels of assets tend to have more credit cards and are more likely to borrow in excess of their annual income. Finally, respondents with higher risk aversion and better numeracy skills are less likely to borrow more than their annual income, which is plausible.

In sum, our results suggest that income smoothing, liquidity constraints and collateral are the main drivers of having debt, in line with economic theory. Moreover, having lower risk 
aversion and worse numeracy skills are related to having relatively high debt compared to income, but financial literacy is an insignificant determinant.

However, there is also slight evidence that there may be a link between excessive debt and financial literacy. Recall that about one in five respondents refused to report their amount of debt. When regressing a dummy for not answering this question against financial literacy, we see a clear negative relationship whilst controlling for the usual socio-demographic variables (results not reported in Table 7). There are two possible reasons for this relationship. Either respondents with low financial literacy simply do not know how much debt they have, and so they cannot answer the question. Alternatively, respondents with low financial literacy and high debt are embarrassed about this, and refuse to answer the question. Either way, this finding helps us better understand the lack of a relationship between borrowing and financial literacy, as respondents engaged in uninformed or excessive borrowing may prefer not to report their debt amount.

Overall, considering savings and borrowings decisions together, we find that financial literacy has a clear effect on the financial decisions of the middle class in Bangkok, and in the expected way: higher financial literacy relates to choosing more advanced savings products and better diversification, and it relates to a more informed use of credit cards.

\subsection{Causal relationships}

Logic may suggest that causality runs from financial literacy to good financial decisions making, but the reverse is also conceivable (Jappelli and Padula, 2013). It is possible that investing in more advanced investment products, such as stocks or mutual funds, provides some kind of financial literacy training and so enables respondents to answer more questions correctly. At the same time, it is possible that OLS regression suffers from endogeneity, caused either by 
unobserved variable bias or by measurement error. The standard approach for dealing with these endogeneity problems in the literature is to analyze the impact of financial literacy with instrumental variables (IV) methods. The main conclusion arising from studies employing IV-methods is that financial literacy has a direct causal effect on wealth accumulation (Behrman et al., 2010, van Rooij et al., 2012), retirement planning (Lusardi and Mitchell, 2017, van Rooij et al., 2011b), stock market participation (van Rooij et al., 2011a) and savings (Klapper et al., 2013). In many cases the effect of financial literacy on the outcome variable becomes larger after changing the methodology from OLS to a specification where financial literacy is instrumented. ${ }^{10}$

To verify the causality of the associations reported so far, we have estimated instrumental variable regressions where we use childhood experiences as instruments for financial literacy. Following Behrman et al. (2010), we search for instruments that do not directly predict the outcome variable (passing an over-identifying restrictions test), while being highly correlated with financial literacy (passing a weak instruments test). Hence childhood experiences with money are particularly suited for this, as they are highly correlated with financial literacy (see, e.g., Behrman et al., 2010, van Rooij et al., 2011b, 2012), but not necessarily correlated with financial behavior in adulthood. As the survey for this paper was designed especially for the purpose of studying financial literacy, we included a large number of potential instruments, all of which refer to the respondents' childhood. Our survey includes questions about the education level of the parents, a rating of the parent's financial understanding, whether the parents taught budgeting and encouraged savings during the respondent's childhood, whether the respondent had economics as a subject in

\footnotetext{
${ }^{10}$ Other papers have tried to solve the potential reverse causality problem by looking at the difference in financial outcomes between those who received financial training and those who did not (see, e.g., Bernheim et al., 2001). However, effects on financial outcomes are often negative, which may be due to ineffective training.
} 
school, and whether they had a bank account before the age of 18 . These variables have previously been used to study the childhood roots of financial literacy (see Grohmann et al., 2015)

Table 8 reports results of two-stage instrumental variable regressions. All childhood variables collected were used as potential instruments for financial literacy in the first-stage regression. For each dependent variable separately, instruments were eliminated if the overidentification test rejected the null hypothesis of no direct relation between the instrument and the dependent variable. Further, weak instruments were deleted if they had low significance in the first-stage regression for explaining financial literacy. The final set of instruments is shown in the third row, and usually consists of only one or two variables. Parents encouraged savings and having a bank account before the age of 18 are most often selected as instruments, followed by the financial understanding of the parents. The first-stage regression results are shown in Table A3 in the Online Appendix.

The first row in Table 8 shows the original marginal effect estimate from a standard probit or count data model, repeated from Table 6 and Table 7, respectively. The second row of Table 8 shows the marginal effect of financial literacy in a two-stage regression, with financial literacy instrumented. All regressions include a full set of socio-economic controls, but to save space the coefficient estimates are not shown. The results in Table 8 show that the impact of financial literacy on financial decisions is causal. Further, in line with the literature, the impact of financial literacy becomes stronger when using an instrumental variables approach. The only exception is the number of different assets owned, for which financial literacy is no longer significant after instrumentation. However, a Wald test also indicates that endogeneity of financial literacy is not an issue for this particular dependent variable. 


\section{Robustness}

We perform a number of robustness tests in order to demonstrate that our findings hold when using other measures of financial literacy, other middle class definitions, and more exclusive definitions of asset ownership. Tables with the results of these tests are shown in the Online Appendix and also shortly described below.

Other measures of financial literacy. Table A4 in the Online Appendix shows results of regressions which reproduce the main specifications of Table 6 and 7 with alternative measures of financial literacy: i) the number of correct answers on the three standard Lusardi-Mitchell financial literacy questions (from 0 to 3), ii) a dummy for answering all three standard Lusardi-Mitchell financial literacy questions correctly (0 or 1), and iii) the number of correct answers on the three standard Lusardi-Mitchell questions, plus an additional borrowing question from Cole et al. (2011) (from 0 to 4). The table shows the estimated marginal effects of the various financial literacy measures, plus the $\mathrm{R}^{2} \mathrm{~s}$. In general, the results for most dependent variables are robust to changing the financial literacy measure.

Other middle class definitions. All results reported in the paper are for a sample of 491 respondents whose family income per household member is between \$10 and \$100 in 2005 dollars, excluding 8 (30) persons whose income is too low (too high). We imposed this sample restriction to focus on the global middle class in developing countries defined by Kharas (2010) and to facilitate comparison with future studies in other countries. When calculating average household income per person, we counted each household member as one, following Kharas (2010). However, in studies analyzing household behavior additional household members and children usually receive lower weights, due to economies of scale. For example, the OECD-modified scale assigns a value of 1 to the household head, 0.5 to each additional adult and 0.3 to each child. Using 
this scale to estimate average income per weighted household member, only one person is too poor ( $<10$ USD per day) and 31 are too rich ( $>100$ USD per day): see Table A1 in the Online Appendix. Table A5 repeats the main analysis of saving and borrowing behavior in this alternative sample of 497 middle class respondents: our findings are effectively the same as before.

We have also repeated the main analysis in Table 6 and Table 7 with the full sample of 530 respondents, and found no substantial changes in the results or conclusions. Overall, the main lesson from these tests is that the exact definition of "middle class", and the exclusion of people on either side of the income scale, does not affect our conclusions.

Other dependent variable definitions. We note that the outcome of the dependent variables for the ownership in Table 6 does not rule out holding other kinds of high-yielding assets, which may bias the estimated effect of financial literacy downwards. For example, a person without a deposit account may actually invest in stocks or bonds. We have estimated the model for ownership of fixed deposits again, but now excluding 49 people who do not own a deposit account, but who do invest in other assets (stocks, bonds or gold): the estimated marginal effect of financial literacy increases from 0.064 to $0.078(+22 \%)$. A similar analysis shows that the negative effect of financial literacy on life insurance ownership also becomes stronger, while the effect of financial literacy on stocks market participation remains unchanged and insignificant.

Controls for occupation and sampling location. To mitigate potential omitted variable bias resulting from the survey design, we have added controls variables for survey location and the respondent's occupation to the regression model used in Table 6 and 7. The results, available upon request, show that the significance of financial literacy and its impact on saving and borrowing behavior is unaffected by the addition of these controls. 


\section{Conclusions}

To our knowledge this is the first study that examines the impact of financial literacy among the middle class living in an urban area in Asia. In contrast to the poor in developing countries, most middle class members, especially those living in urban areas, have access to a wide range of saving products and borrowing channels. However, little is known about how effectively the middle class uses these financial services, and to what extent a lack of financial literacy is an obstacle.

In this paper we first show that the average level of financial literacy of the middle class in Bangkok is similar to developed countries. However, knowledge about stock market diversification is lacking, with only $24 \%$ answering this question correctly. Moreover, we are able to show that financial literacy has two main benefits. First, financially literate individuals are more likely to own as assets other than a savings account and are more likely to own a fixed deposit account. They are also less likely to own life insurance, which gives notoriously low returns. Hence this study shows that middle class respondents with higher financial literacy are more likely to use the wide range of financial services that is offered to them. Second, they use credit cards in a more informed way: they are more likely to know the interest rate on credit card and have less difficulty paying off credit card debt. Finally, these links from financial literacy to financial behavior are causal, as demonstrated through IV regressions.

In our sample we find no support for the expected positive link between financial literacy and stock market participation that is often found in developed markets. Taken together with the documented low knowledge of stock market diversification, our results suggest that building better understanding of stock markets may be among the important policy targets for raising the financial literacy of the middle class in developing countries. 
As an avenue for future research, a relevant question is whether improving the financial literacy of the middle class in developing countries has benefits beyond improving individual welfare. We expect that financial literacy is an important component in three out of five channels though which financial development leads to growth (Levine, 2005): more efficient mobilization of savings, better risk management and improving the exchange of goods and services. Crosscountry studies can investigate these potential macro-economic benefits.

\section{Acknowledgments}

We would like to thank participants at several seminars, in particular Andre Güttler, Christine Kaufmann, Stephan Klasen, Sandra Ludwig, Olivia Mitchell, Martin Weber and two anonymous referees for helpful comments. Special thanks to Roy Kouwenberg and Lukas Menkhoff for their advice and to Atcha Kamolsareeratana for her assistance. Financial support by the German Research Foundation (DFG, grant RTG 1723) is gratefully acknowledged. 


\section{References}

Abreu, M. and V. Mendes (2010), Financial Literacy and Portfolio Diversification, Quantitative Finance, 10, 515-528.

Ameriks, J., A. Caplin and J. Leahy (2003), Wealth Accumulation and the Propensity to Plan, Quarterly Journal of Economics, 118, 1007-1047.

Banerjee, A. and E. Duflo, What is Middle-class abou the Middle-classes around the World, Journal of Economic Perspectives, 22(2), 3-28.

Beckmann, E. (2013), Financial Literacy and Household Savings in Romania, Numeracy, 6:2, Article 9.

Behrman, J.R., O.S. Mitchell, C.K. Soo and D. Bravo (2010), Financial Literacy, Schooling and Wealth Accumulation, NBER Working Paper 16452.

Bernheim, B.D., D.M. Garrett and D.M. Maki (2001), Education and Saving: The Long-term Effects of High School Financial Curriculum Mandates, Journal of Public Economics, 80, 435-465.

Bucher-Koenen, T. and A. Lusardi (2015), Financial Literacy and Retirement Planning in Germany, Journal of Pension Economics and Finance, 10, 565-584.

Campbell, J.Y. (2006), Household Finance, Journal of Finance, 61, 1553-1604.

Carpena, F., S. Cole, J. Shapiro and B. Zia (2011), Unpacking the Causal Chain of Financial Literacy, World Bank Policy Research Paper 5798.

Christiansen, C., J. Schröter Joensen and J. Rangvid, (2008), Are Economists More Likely to Hold Stocks, Review of Finance, 12, 465-496 
Chun, N., R.Hasan, M. Habibur Rahman, and M. a. Ulubasoglu, The Role of Middle Class in Economic Development: What Do Cross-Country Data Show?, Review of Development Economics, 21(2). 404-424.

Cole, S., T. Sampson and B. Zia (2011), Prices or Knowledge? What Drives Demand for Financial Services in Emerging Markets? Journal of Finance, 66, 1933-1967.

Disney, R. and J, Gathergood (2013), Financial Literacy and Consumer Credit Portfolios, Journal of Banking and Finance, 37, 2246-2254.

Dohmen, T., A. Falk, D. Huffmann, U. Sunde, J. Schupp, and G.G. Wagner (2011), Individual Risk Attitudes: Measurement, Determinants and Behavioral Consequences, Journal of the European Economic Association, 9, 522-50.

Fernandes, D., J.G. Lynch Jr. and R.G. Netemeyer (2014), Financial Literacy, Financial Education and Downstream Financial Behaviors, Management Science, 60, 1861-1883.

Gathergood, J. (2012), Self-Control, Financial Literacy and Consumer Over-Indebtedness, Journal of Economic Psychology, 33, 590-602.

Guiso, L. and T. Jappelli (2008), Financial Literacy and Portfolio Choice, EUI Working Papers, ECO2008/31.

Guiso, L. and P. Sodini (2013), Household Finance: An Emerging Field, In: George M. Constantinides, Milton Harris and Rene M. Stulz (Editors), Handbook of the Economics of Finance, Volume 2, Part B, Elsevier, 1397-1532.

Gustman, A.L., T.L. Steinmeier and N. Tabatabai (2012), Financial Knowledge and Financial Literacy at the Household Level, American Economic Review Papers and Proceedings, 102:3, 309-313. 
Grohmann, A., R.Kouwenberg and L. Menkhoff (2015), Childhood Roots of Financial Literacy, Journal of Economic Psychology, 51, 114-133.

Grohmann, A., O.Huebler, R.Kouwenberg and L. Menkhoff (2016), Financial Literacy. Thai Middle Class Women do not Lag Behind, DIW Working Paper Series No. 1615.

Hardeweg, B., L. Menkhoff and H. Waibel (2013), Experimentally Validated Survey Evidence on Individual Risk Attitudes in Rural Thailand, Economic Development and Cultural Change, 61, 859-888.

Hastings, J.S. and L. Tejeda-Ashton (2008), Financial Literacy, Information and Demand Elasticity: Survey and Experimental Evidence from Mexico, NBER Working Paper 14538.

Jappelli, T. and M. Padula (2013), Investment in Financial Literacy and Saving Decisions, Journal of Banking and Finance, 37, 2779-2792.

Kaiser, Tim and Lukas Menkhoff (2017), Does Financial Education impact Financial Literacy, and if so, when? The World Bank Economic Review, 31(3), 611-630.

Kharas, H. (2010), The Emerging Middle Class in Developing Countries, OECD Development Centre, Working Paper 285.

Kharas, H. and G. Gertz (2010), The New Global Middle Class: A Cross-Over from West to East, In: Cheng Li (ed.), China's Emerging Middle Class: Beyond Economic Transformation, Chapter 2, Brookings Institution Press.

Klapper, L., A. Lusardi and G.A. Panos (2013), Financial Literacy and its Consequences: Evidence from Russia during the Financial Crisis, Journal of Banking and Finance, 37, 3904-3923.

Klapper, L., and G.A. Panos (2011), Financial Literacy and Retirement Planning: The Russian Case, Journal of Pension Economics and Finance, 10, 599-618. 
Landerretche, O. M., and C. Martinez (2013), Voluntary Savings, Financial Behavior, and Pension Finance Literacy: Evidence from Chile, Journal of Pension Economics and Finance, 12, 251-297.

Levine, R. (2005), Finance and Growth: Theory and Evidence, In: Aghion, P. and Durlauf, S. (eds.), Handbook of Economic Growth, Volume 1A, Chapter 12, Elsevier, 865-34.

Lusardi, A. and O.S. Mitchell (2007), Baby Boomer Retirement Security: The Roles of Planning, Financial Literacy, and Housing Wealth, Journal of Monetary Economics, 54, 205-224.

Lusardi, A. and O.S. Mitchell (2017), How Ordinary Consumers Make Complex Economic Decisions: Financial Literacy and Retirement Readiness, Quarterly Journal of Finance, 7(03), 175008.

Lusardi, A. and O.S. Mitchell (2011), Financial Literacy around the World: An Overview, Journal of Pension Economics and Finance, 10, 497-508.

Lusardi, A. and O.S. Mitchell (2014), The Economic Importance of Financial Literacy: Theory and Evidence, Journal of Economic Literature, 52, 5-44.

Lusardi, A., O.S. Mitchell and V. Curto (2010), Financial Literacy among the Young, Journal of Consumer Affairs, 44, 358-380.

Lusardi, A., and P. Tufano (2015), Debt Literacy, Financial Experiences, and Overindebtedness, Journal of Pension Economics and Finance, 14, 332-368.

Meier, S. and C.D. Sprenger (2013), Discounting Financial Literacy: Time Preference and Participation in Financial Education Programs, Journal of Economic Behavior and Organization, 95, 159-174.

Murphy, K.M., A. Shleifer and R. Vishny (1989), Income Distribution, Market Size, and Industrialization, Quarterly Journal of Economics, 104, 537-564. 
Ravallion, M. (2010), The Developing World's Bulging (but Vulnerable) Middle Class, World Development, 38, 445-454.

Stango, V. and J. Zinman (2009), Exponential Growth Bias and Household Finance, Journal of Finance, 64, 2807-2849.

Van Rooij, M.C.J., A. Lusardi and R. Alessie (2011a), Financial Literacy and Stock Market Participation, Journal of Financial Economics, 101, 449-472.

Van Rooij, M.C.J., A. Lusardi and R. Alessie (2011b), Financial Literacy and Retirement Planning in the Netherlands, Journal of Economic Psychology, 32, 593-608

Van Rooij, M.C.J., A. Lusardi and R. Alessie (2012), Financial Literacy, Retirement Planning and Household Wealth, Economic Journal, 122, 449-478.

Xu, L. and B. Zia (2012), Financial Literacy around the World: An Overview of the Evidence with Practical Suggestions for the Way Forward, World Bank Policy Research Working Paper 6107.

Xu, L. and B. Zia (2013), Financial Literacy in the Developing World, Working Paper. 


\section{Table 1: Summary Statistics}

Panel A: Demographics

\begin{tabular}{|c|c|c|c|c|c|}
\hline & mean & median & stdev & $\min$ & $\max$ \\
\hline Female (\%) & $47 \%$ & 0 & $50 \%$ & 0 & $100 \%$ \\
\hline Age in years & 34.49 & 32.0 & 9.50 & 18 & 60 \\
\hline Married (\%) & $46 \%$ & 0 & $50 \%$ & 0 & $100 \%$ \\
\hline Personal income (Baht) ${ }^{*}$ & 26,467 & 20,000 & 19,023 & 15,000 & 200,000 \\
\hline Household income (Baht) ${ }^{*}$ & 58,457 & 50,000 & 42,222 & 15,000 & 300,000 \\
\hline Number of children in $\mathrm{HH}$ & 0.75 & 0 & 0.97 & 0 & 6 \\
\hline Number of adults in $\mathrm{HH}$ & 2.86 & 3.0 & 1.43 & 1 & 11 \\
\hline $\begin{array}{l}\text { Daily income per household } \\
\text { member in } 2005 \text { USD }\end{array}$ & 28.99 & 25.0 & 15.18 & 10.0 & 83.5 \\
\hline \multicolumn{6}{|c|}{$\begin{array}{l}\text { The sample consists of } \mathrm{N}=491 \text { respondents who have daily income per household member in } 2005 \text { USD } \\
\text { (at PPP exchange rates) between } \$ 10 \text { and } \$ 100 \text {, meeting the global middle class definition of Kharas (2010). } \\
{ }^{*} \text { Monthly amount in Thai Baht }\end{array}$} \\
\hline \multicolumn{6}{|l|}{ Panel B: Education } \\
\hline & & \multicolumn{2}{|r|}{ Percent } & \multicolumn{2}{|c|}{$\mathrm{N}$} \\
\hline No education & & \multicolumn{2}{|r|}{$0.4 \%$} & \multicolumn{2}{|c|}{2} \\
\hline Primary school & & \multicolumn{2}{|r|}{$3.9 \%$} & \multicolumn{2}{|c|}{19} \\
\hline Secondary school & & \multicolumn{2}{|r|}{$12.8 \%$} & \multicolumn{2}{|c|}{63} \\
\hline Vocational & & \multicolumn{2}{|r|}{$14.1 \%$} & \multicolumn{2}{|c|}{69} \\
\hline Bachelor degree & & \multicolumn{2}{|r|}{$66.0 \%$} & \multicolumn{2}{|c|}{324} \\
\hline Masters degree & & \multicolumn{2}{|r|}{$2.6 \%$} & \multicolumn{2}{|c|}{13} \\
\hline $\mathrm{PhD}$ & & \multicolumn{2}{|r|}{$0.2 \%$} & \multicolumn{2}{|c|}{1} \\
\hline Total & & \multicolumn{2}{|r|}{$100.0 \%$} & \multicolumn{2}{|c|}{491} \\
\hline
\end{tabular}


Table 2: Financial Literacy

Panel A: Responses to Financial Literacy Questions

\begin{tabular}{|c|c|c|c|c|}
\hline & Correct & Wrong & Don't Know & $\begin{array}{c}\text { Refuse to } \\
\text { Answer }\end{array}$ \\
\hline Interest rate & $80.9 \%$ & $14.1 \%$ & $4.9 \%$ & $0.2 \%$ \\
\hline Inflation & $63.5 \%$ & $24.2 \%$ & $11.4 \%$ & $0.8 \%$ \\
\hline Diversification & $23.8 \%$ & $24.2 \%$ & $50.3 \%$ & $1.6 \%$ \\
\hline
\end{tabular}

Panel B: Financial Literacy Measures

\begin{tabular}{lccccc}
\hline & mean & median & stdev & min & max \\
\hline $\begin{array}{l}\text { Sum correct 3 basic questions } \\
\quad \text { (Lusardi-Mitchell) }\end{array}$ & 1.68 & 2.00 & 0.87 & 0 & 3 \\
$\begin{array}{c}\text { Total number of foreign banks } \\
\text { named }\end{array}$ & 2.25 & 2.00 & 1.20 & 0 & 6 \\
$\begin{array}{l}\text { Score between 0 and 1 for naming } \\
\text { foreign banks }\end{array}$ & 0.56 & 0.50 & 0.30 & 0 & 1 \\
$\begin{array}{l}\text { Sum correct 3 basic questions and } \\
\quad \text { name banks score out of 4 } \\
\text { (Lusardi-Mitchell + Banks) }\end{array}$ & 2.24 & 2.50 & 0.99 & 0 & 4 \\
\hline
\end{tabular}

Panel C: Correlations

\begin{tabular}{|c|c|c|c|c|}
\hline & Interest Rate & Inflation & Diversification & $\begin{array}{l}\text { Name } \\
\text { Foreign } \\
\text { Banks }\end{array}$ \\
\hline Interest rate & 1.00 & & & \\
\hline Inflation & $0.19 * * *$ & 1.00 & & \\
\hline Diversification & 0.05 & $0.25 * * *$ & 1.00 & \\
\hline Naming foreign banks & 0.06 & $0.18 * *$ & $0.26 * * *$ & 1.00 \\
\hline \multicolumn{5}{|c|}{$\begin{array}{l}* * *, * * \text { and } * \text { denote significance at the } 1 \%, 5 \% \text { and } 10 \% \text { levels, respectively } \\
\text { The sample consists of } \mathrm{N}=491 \text { respondents who have daily income per household member in } 2005 \text { USD } \\
\text { (at PPP exchange rates) between } \$ 10 \text { and } \$ 100 \text {, meeting the global middle class definition of Kharas (2010). }\end{array}$} \\
\hline \multicolumn{5}{|c|}{$\begin{array}{l}\text { Notes: The financial literacy questions are repeated below. The first three questions are multiple } \\
\text { responses "I don't know" and "I refuse to answer" are available in addition to the listed options. } \\
\text { 1. Interest rate: If you borrow } 10,000 \text { Baht at an interest rate of } 2 \% \text { a month, after } 3 \text { months hon } \\
\text { Options: a) Less than } 10,200 \text { Baht, b) More than } 10,200 \text { Baht, c) Exactly } 10,200 \text { Baht. } \\
\text { 2. Inflation: If you have } 10,000 \text { Baht in an account, the interest rate on the account is } 1 \% \text { per yec } \\
\text { goods and services rises by } 2 \% \text { per year, after one year can you buy? } \\
\text { Options: a) Less than today, b) More than today, c) Exactly the same as today. } \\
\text { 3. Diversification: Buying a single company's stock is safer than buying a stock mutual fund. } \\
\text { Options: a) True, b) False } \\
\text { 4. Institutional knowledge: Name foreign banks. Open answers }\end{array}$} \\
\hline
\end{tabular}




\section{Table 3: Numeracy and Risk Aversion}

Panel A: Numeracy Question

\begin{tabular}{lcccc}
\hline & & & & Refuse to \\
& Correct (\%) & Wrong & Don’t know & Answer \\
\hline $35+82$ & $84.7 \%$ & $10.4 \%$ & $2.2 \%$ & $2.6 \%$ \\
4 friends, 4 sweets $^{\text {a }}$ & $84.5 \%$ & $12.0 \%$ & $0.4 \%$ & $3.1 \%$ \\
$10 \%$ of 400 & $94.5 \%$ & $1.4 \%$ & $1.4 \%$ & $2.6 \%$ \\
$1000-370{ }^{\text {b }}$ & $95.3 \%$ & $1.6 \%$ & $0.2 \%$ & $2.9 \%$
\end{tabular}

${ }^{\mathrm{a}}$ The question asks, if you have four friends and you want to give each friend four sweets, how many sweets do you need? ${ }^{\mathrm{b}}$ If you buy a bag of rice for 370 Baht and you pay with 1000 Baht note, how much change do you get?

Panel B: Statistics of Numeracy and Risk Aversion

\begin{tabular}{lccccc}
\hline & mean & median & stdev & min & max \\
\hline Numeracy score out of 4 & 3.59 & 4 & 0.85 & 0 & 4 \\
Scale of risk taker & 5.54 & 6 & 2.20 & 0 & 10 \\
$\quad$ Risk aversion scale $(0-1)$ & 0.45 & 0.40 & 0.22 & 0 & 1 \\
\hline
\end{tabular}

Panel C: Correlations

\begin{tabular}{lccc}
\hline & Numeracy & $\begin{array}{c}\text { Risk aversion } \\
\text { scale }\end{array}$ & $\begin{array}{c}\text { Financial } \\
\text { Literacy } \\
\text { (3+banks) }\end{array}$ \\
\hline Numeracy & 1 & 1 & \\
Risk aversion scale & $-0.25^{* * *}$ & $-0.37^{* * *}$ & 1 \\
Financial literacy (3+banks) & $0.23^{* * *}$ & -0.60 \\
\hline
\end{tabular}

***, $* *$ and $*$ denote significance at the $1 \%, 5 \%$ and $10 \%$ levels, respectively 
Table 4: Distribution of Financial Literacy across Demographic and Income Groups

\begin{tabular}{|c|c|c|c|c|c|c|c|c|c|c|}
\hline & Obs. & $\begin{array}{l}\text { Percent. } \\
\text { in group }\end{array}$ & $\begin{array}{c}\text { Financial l } \\
\text { Interest } \\
\text { correct \% }\end{array}$ & $\begin{array}{l}\text { teracy quest } \\
\text { Inflation } \\
\text { correct \% }\end{array}$ & $\begin{array}{l}\text { ons (Lusard } \\
\text { Stock risk } \\
\text { correct \% }\end{array}$ & $\begin{array}{l}\text {-Mitchell) } \\
\text { All three } \\
\text { correct \% }\end{array}$ & $\begin{array}{r}\text { Foreign } \\
\text { banks } \\
(0-4) \\
\text { mean } \\
\end{array}$ & $\begin{array}{r}\text { Financial } \\
\text { literacy } \\
(0-4) \\
\text { mean } \\
\end{array}$ & $\begin{array}{r}\text { Risk } \\
\text { aversion } \\
(0-1) \\
\text { mean } \\
\end{array}$ & $\begin{array}{r}\text { Numeracy } \\
(0-4) \\
\text { mean } \\
\end{array}$ \\
\hline \multicolumn{11}{|l|}{ Gender } \\
\hline Male & 259 & $53 \%$ & $81 \%$ & $64 \%$ & $23 \%$ & $16 \%$ & 2.19 & 2.22 & 0.43 & 3.58 \\
\hline Female & 232 & $47 \%$ & $81 \%$ & $63 \%$ & $25 \%$ & $19 \%$ & 2.31 & 2.27 & 0.47 & 3.61 \\
\hline \multicolumn{11}{|l|}{ Age } \\
\hline$<35$ years & 277 & $56 \%$ & $82 \%$ & $66 \%$ & $25 \%$ & $18 \%$ & 2.26 & 2.30 & 0.44 & 3.68 \\
\hline 35 - 50 years & 173 & $35 \%$ & $82 \%$ & $58 \%$ & $20 \%$ & $15 \%$ & 2.21 & 2.15 & 0.45 & 3.53 \\
\hline$>50$ years & 41 & $8 \%$ & $71 \%$ & $66 \%$ & $34 \%$ & $22 \%$ & 2.37 & 2.30 & 0.49 & 3.24 \\
\hline \multicolumn{11}{|l|}{ Education } \\
\hline Secondary or lower & 84 & $17 \%$ & $63 \%$ & $51 \%$ & $11 \%$ & $2 \%$ & 1.73 & 1.68 & 0.52 & 3.13 \\
\hline Vocational & 69 & $14 \%$ & $84 \%$ & $61 \%$ & $36 \%$ & $26 \%$ & 2.10 & 2.33 & 0.48 & 3.72 \\
\hline Bachelor or higher & 338 & $69 \%$ & $85 \%$ & $67 \%$ & $25 \%$ & $20 \%$ & 2.41 & 2.37 & 0.42 & 3.68 \\
\hline \multicolumn{11}{|l|}{ Income } \\
\hline$<17,500$ & 166 & $34 \%$ & $77 \%$ & $58 \%$ & $17 \%$ & $8 \%$ & 2.08 & 2.03 & 0.49 & 3.49 \\
\hline $17,500-22,500$ & 150 & $31 \%$ & $77 \%$ & $59 \%$ & $19 \%$ & $14 \%$ & 2.22 & 2.12 & 0.45 & 3.55 \\
\hline $22,500-37,500$ & 101 & $21 \%$ & $87 \%$ & $72 \%$ & $30 \%$ & $27 \%$ & 2.39 & 2.48 & 0.39 & 3.74 \\
\hline$>37,500$ & 74 & $15 \%$ & $89 \%$ & $73 \%$ & $41 \%$ & $34 \%$ & 2.50 & 2.65 & 0.42 & 3.70 \\
\hline \multicolumn{11}{|l|}{ Financial assets } \\
\hline Refuse/ don't know & 100 & $20 \%$ & $82 \%$ & $50 \%$ & $17 \%$ & $12 \%$ & 1.92 & 1.97 & 0.45 & 3.68 \\
\hline$<100,000$ & 243 & $49 \%$ & $79 \%$ & $65 \%$ & $21 \%$ & $14 \%$ & 2.34 & 2.25 & 0.44 & 3.63 \\
\hline $100,000-500,000$ & 110 & $22 \%$ & $84 \%$ & $68 \%$ & $26 \%$ & $24 \%$ & 2.42 & 2.38 & 0.44 & 3.43 \\
\hline$>500,000$ & 38 & $8 \%$ & $79 \%$ & $74 \%$ & $50 \%$ & $34 \%$ & 2.08 & 2.55 & 0.47 & 3.61 \\
\hline
\end{tabular}

The sample consists of $\mathrm{N}=491$ respondents who have daily income per household member in 2005 USD (at PPP exchange rates) between $\$ 10$ and $\$ 100$, meeting the global middle class definition of Kharas (2010). 
Table 5: Savings and Borrowings Summary Statistics

Panel A: Assets

\begin{tabular}{|c|c|c|c|c|c|}
\hline & mean & stdev & $\min$ & $\max$ & count \\
\hline Has a savings account & $100 \%$ & $0 \%$ & 1 & 1 & 491 \\
\hline Owns fixed deposit accounts & $42 \%$ & $49 \%$ & 0 & 1 & 491 \\
\hline Owns a government savings bank deposit & $2 \%$ & $15 \%$ & 0 & 1 & 491 \\
\hline Owns bonds or bond mutual funds & $11 \%$ & $31 \%$ & 0 & 1 & 490 \\
\hline Owns stocks or equity mutual funds & $8 \%$ & $27 \%$ & 0 & 1 & 489 \\
\hline Owns gold & $8 \%$ & $26 \%$ & 0 & 1 & 488 \\
\hline Owns life insurance & $16 \%$ & $37 \%$ & 0 & 1 & 491 \\
\hline Financial Assets $<100,000$ & $49 \%$ & $50 \%$ & 0 & 1 & 491 \\
\hline $100,000<$ Financial Assets $<500,000$ Baht & $22 \%$ & $42 \%$ & 0 & 1 & 491 \\
\hline Financial Assets > 500,000 Baht & $8 \%$ & $27 \%$ & 0 & 1 & 491 \\
\hline Did not provide financial assets amount & $20 \%$ & $40 \%$ & 0 & 1 & 491 \\
\hline Owns $>=2$ types of assets ${ }^{\mathrm{a}}$ & $53 \%$ & $50 \%$ & 0 & 1 & 487 \\
\hline $\begin{array}{l}\text { Number of asset types owned, } \\
\text { apart from a savings account }{ }^{\mathrm{a}}\end{array}$ & 0.75 & 0.88 & 0 & 4 & 487 \\
\hline \multicolumn{6}{|c|}{$\begin{array}{l}{ }^{\mathrm{a}} \text { Includes fixed deposit accounts, government savings bank deposits, bonds or bond funds, stocks or stock funds, and } \\
\text { gold. It excludes life insurance. }\end{array}$} \\
\hline \multicolumn{6}{|l|}{ Panel B: Debt } \\
\hline & mean & stdev & $\min$ & $\max$ & count \\
\hline Has any debt & $47 \%$ & $50 \%$ & 0 & 1 & 473 \\
\hline Amount of debt in Baht & 93,383 & 332,977 & 0 & $3,000,000$ & 376 \\
\hline $\begin{array}{l}\text { Amount of debt in Baht } \\
\text { (conditional on having debt) }\end{array}$ & 256,292 & 513,477 & 0 & $3,000,000$ & 137 \\
\hline Debt larger than annual income & $7 \%$ & $26 \%$ & 0 & 1 & 376 \\
\hline $\begin{array}{l}\text { Debt larger than annual income } \\
\text { (conditional on having debt) }\end{array}$ & $20 \%$ & $40 \%$ & 0 & 1 & 137 \\
\hline Number of credit cards & 0.62 & 1.09 & 0 & 7 & 491 \\
\hline Has at least one credit card & $34 \%$ & $47 \%$ & 0 & 1 & 491 \\
\hline $\begin{array}{l}\text { Finds it difficult to pay off credit card } \\
\text { (conditional on having a credit card) }\end{array}$ & $15 \%$ & $36 \%$ & 0 & 1 & 163 \\
\hline $\begin{array}{l}\text { Does NOT know interest on credit card } \\
\text { (conditional on having credit card) }\end{array}$ & $57 \%$ & $50 \%$ & 0 & 1 & 165 \\
\hline
\end{tabular}


Table 6: Savings, Assets and Financial Literacy

\begin{tabular}{|c|c|c|c|c|}
\hline & $\begin{array}{l}\text { (1) } \\
\text { Assets other } \\
\text { than savings } \\
\text { account }\end{array}$ & $\begin{array}{l}(2) \\
\text { Fixed } \\
\text { deposits }\end{array}$ & $\begin{array}{l}\text { (3) } \\
\text { Stocks }\end{array}$ & $\begin{array}{l}\text { (4) } \\
\text { Insurance }\end{array}$ \\
\hline Financial literacy & $\begin{array}{l}0.078 * * * \\
{[0.022]}\end{array}$ & $\begin{array}{l}0.064^{* * *} \\
{[0.023]}\end{array}$ & $\begin{array}{l}0.009 \\
{[0.009]}\end{array}$ & $\begin{array}{l}-0.032 * * \\
{[0.015]}\end{array}$ \\
\hline Numeracy & $\begin{array}{l}0.052 * \\
{[0.027]}\end{array}$ & $\begin{array}{l}0.036 \\
{[0.027]}\end{array}$ & $\begin{array}{l}-0.013 \\
{[0.009]}\end{array}$ & $\begin{array}{l}-0.060 * * * \\
{[0.015]}\end{array}$ \\
\hline Risk aversion & $\begin{array}{l}-0.088 \\
{[0.104]}\end{array}$ & $\begin{array}{l}-0.164 \\
{[0.103]}\end{array}$ & $\begin{array}{l}0.050 \\
{[0.048]}\end{array}$ & $\begin{array}{l}0.183 * * * \\
{[0.063]}\end{array}$ \\
\hline Higher education & $\begin{array}{l}0.147 * * * \\
{[0.041]}\end{array}$ & $\begin{array}{l}0.128 * * * \\
{[0.044]}\end{array}$ & $\begin{array}{l}0.063 * * \\
{[0.025]}\end{array}$ & $\begin{array}{l}0.101^{* * *} \\
{[0.033]}\end{array}$ \\
\hline Female & $\begin{array}{l}0.085 * * \\
{[0.038]}\end{array}$ & $\begin{array}{l}0.100^{* *} \\
{[0.039]}\end{array}$ & $\begin{array}{l}-0.029 \\
{[0.020]}\end{array}$ & $\begin{array}{l}0.034 \\
{[0.027]}\end{array}$ \\
\hline Age & $\begin{array}{l}0.036 * * \\
{[0.018]}\end{array}$ & $\begin{array}{l}0.022 \\
{[0.017]}\end{array}$ & $\begin{array}{l}0.004 \\
{[0.009]}\end{array}$ & $\begin{array}{l}0.012 \\
{[0.012]}\end{array}$ \\
\hline Age squared / 100 & $\begin{array}{l}-0.041^{*} \\
{[0.025]}\end{array}$ & $\begin{array}{l}-0.019 \\
{[0.023]}\end{array}$ & $\begin{array}{l}-0.004 \\
{[0.011]}\end{array}$ & $\begin{array}{l}-0.015 \\
{[0.015]}\end{array}$ \\
\hline No of children in $\mathrm{HH}$ & $\begin{array}{l}-0.015 \\
{[0.022]}\end{array}$ & $\begin{array}{l}-0.019 \\
{[0.021]}\end{array}$ & $\begin{array}{l}-0.015 \\
{[0.011]}\end{array}$ & $\begin{array}{l}-0.036^{* *} \\
{[0.016]}\end{array}$ \\
\hline No of adults in $\mathrm{HH}$ & $\begin{array}{l}0.014 \\
{[0.014]}\end{array}$ & $\begin{array}{l}0.005 \\
{[0.014]}\end{array}$ & $\begin{array}{l}0.009 \\
{[0.007]}\end{array}$ & $\begin{array}{l}0.019 * \\
{[0.010]}\end{array}$ \\
\hline Log of income & $\begin{array}{l}0.296 * * * \\
{[0.072]}\end{array}$ & $\begin{array}{l}0.216^{* * *} \\
{[0.061]}\end{array}$ & $\begin{array}{l}0.067 * * * \\
{[0.024]}\end{array}$ & $\begin{array}{l}0.045 \\
{[0.037]}\end{array}$ \\
\hline Assets low dummy & $\begin{array}{l}-0.148^{* * *} \\
{[0.051]}\end{array}$ & $\begin{array}{l}-0.144^{* * *} \\
{[0.052]}\end{array}$ & $\begin{array}{l}-0.032 \\
{[0.024]}\end{array}$ & $\begin{array}{l}-0.190^{* * *} \\
{[0.035]}\end{array}$ \\
\hline Assets high dummy & $\begin{array}{l}0.125 \\
{[0.101]}\end{array}$ & $\begin{array}{l}-0.102 \\
{[0.092]}\end{array}$ & $\begin{array}{l}0.104^{* * *} \\
{[0.026]}\end{array}$ & $\begin{array}{l}0.163 * * * \\
{[0.043]}\end{array}$ \\
\hline $\begin{array}{l}\text { Assets amount } \\
\text { missing dummy }\end{array}$ & $\begin{array}{l}-0.098 \\
{[0.060]}\end{array}$ & $\begin{array}{l}-0.053 \\
{[0.062]}\end{array}$ & $\begin{array}{l}-0.026 \\
{[0.033]}\end{array}$ & $\begin{array}{l}-0.062 \\
{[0.039]}\end{array}$ \\
\hline Mean of dependent var. & 0.53 & 0.42 & 0.08 & 0.16 \\
\hline Pseudo-R² & 0.26 & 0.18 & 0.37 & 0.34 \\
\hline Observations & 487 & 491 & 489 & 491 \\
\hline
\end{tabular}

Notes: The table reports marginal effects, with robust standard errors in brackets. The dependent variable of the regression models is: (1) a dummy for owning assets other than a savings account, (2) a dummy for owning fixed deposit accounts, (3) a dummy for owning stocks or equity mutual funds, (4) a dummy for owning life insurance, and (5) the number of asset types owned (excluding savings accounts). Results in Column (1) to (4) use probit regression models, and Column (5) is based on a Poisson count data regression model. The row "Mean of dependent var." displays the sample mean of the dependent variable to facilitate the interpretation of marginal effect sizes. ${ }^{* * *}, * *$ and $*$ denote significance at the $1 \%, 5 \%$ and $10 \%$ levels, respectively 
Table 7: Borrowing Behavior and Financial Literacy

\begin{tabular}{|c|c|c|c|c|}
\hline & \begin{tabular}{l}
\multicolumn{1}{c}{$(1)$} \\
Does not know \\
interest rate on \\
credit card \\
\end{tabular} & $\begin{array}{l}\quad(2) \\
\text { Has difficulty } \\
\text { paying off } \\
\text { credit card } \\
\end{array}$ & $\begin{array}{l}\text { (3) } \\
\text { Number of } \\
\text { credit cards }\end{array}$ & \begin{tabular}{l}
\multicolumn{1}{c}{$(4)$} \\
Debt larger \\
than annual \\
income \\
\end{tabular} \\
\hline Financial literacy & $\begin{array}{l}-0.125^{* * *} \\
{[0.040]}\end{array}$ & $\begin{array}{l}-0.063^{* *} \\
{[0.032]}\end{array}$ & $\begin{array}{l}0.043 \\
{[0.058]}\end{array}$ & $\begin{array}{l}-0.015 \\
{[0.012]}\end{array}$ \\
\hline Numeracy & $\begin{array}{l}-0.029 \\
{[0.070]}\end{array}$ & $\begin{array}{l}-0.048 \\
{[0.045]}\end{array}$ & $\begin{array}{l}0.113 \\
{[0.069]}\end{array}$ & $\begin{array}{l}-0.030 * * \\
{[0.012]}\end{array}$ \\
\hline Risk aversion & $\begin{array}{l}0.009 \\
{[0.186]}\end{array}$ & $\begin{array}{l}0.038 \\
{[0.130]}\end{array}$ & $\begin{array}{l}-0.349 \\
{[0.266]}\end{array}$ & $\begin{array}{l}-0.136 * * \\
{[0.056]}\end{array}$ \\
\hline Higher education & $\begin{array}{l}-0.107 \\
{[0.090]}\end{array}$ & $\begin{array}{l}-0.055 \\
{[0.059]}\end{array}$ & $\begin{array}{l}0.278^{* *} \\
{[0.132]}\end{array}$ & $\begin{array}{l}0.014 \\
{[0.030]}\end{array}$ \\
\hline Female & $\begin{array}{l}0.107 \\
{[0.073]}\end{array}$ & $\begin{array}{l}-0.114^{* *} \\
{[0.056]}\end{array}$ & $\begin{array}{l}0.078 \\
{[0.100]}\end{array}$ & $\begin{array}{l}-0.038 \\
{[0.024]}\end{array}$ \\
\hline Age & $\begin{array}{l}-0.003 \\
{[0.033]}\end{array}$ & $\begin{array}{l}-0.037 \\
{[0.025]}\end{array}$ & $\begin{array}{l}0.119 * * * \\
{[0.042]}\end{array}$ & $\begin{array}{l}0.034^{* *} \\
{[0.013]}\end{array}$ \\
\hline Age squared / 100 & $\begin{array}{l}0.004 \\
{[0.041]}\end{array}$ & $\begin{array}{l}0.045 \\
{[0.032]}\end{array}$ & $\begin{array}{l}-0.149 * * * \\
{[0.054]}\end{array}$ & $\begin{array}{l}-0.042 * * \\
{[0.017]}\end{array}$ \\
\hline No of children in $\mathrm{HH}$ & $\begin{array}{l}0.019 \\
{[0.037]}\end{array}$ & $\begin{array}{l}0.023 \\
{[0.027]}\end{array}$ & $\begin{array}{l}0.086 \\
{[0.062]}\end{array}$ & $\begin{array}{l}0.010 \\
{[0.013]}\end{array}$ \\
\hline No of adults in $\mathrm{HH}$ & $\begin{array}{l}0.058 * * \\
{[0.024]}\end{array}$ & $\begin{array}{l}-0.006 \\
{[0.017]}\end{array}$ & $\begin{array}{l}0.040 \\
{[0.038]}\end{array}$ & $\begin{array}{l}-0.017 \\
{[0.013]}\end{array}$ \\
\hline Log of income & $\begin{array}{l}-0.200 * \\
{[0.103]}\end{array}$ & $\begin{array}{l}0.036 \\
{[0.067]}\end{array}$ & $\begin{array}{l}0.424^{* *} \\
{[0.169]}\end{array}$ & $\begin{array}{l}-0.009 \\
{[0.035]}\end{array}$ \\
\hline Assets low dummy & $\begin{array}{l}-0.043 \\
{[0.101]}\end{array}$ & $\begin{array}{l}-0.022 \\
{[0.076]}\end{array}$ & $\begin{array}{l}-0.035 \\
{[0.147]}\end{array}$ & $\begin{array}{l}-0.065^{* *} \\
{[0.032]}\end{array}$ \\
\hline Assets high dummy & $\begin{array}{l}0.271 * * \\
{[0.120]}\end{array}$ & $\begin{array}{l}-0.058 \\
{[0.093]}\end{array}$ & $\begin{array}{l}0.388^{* *} \\
{[0.165]}\end{array}$ & $\begin{array}{l}0.088^{* *} \\
{[0.035]}\end{array}$ \\
\hline $\begin{array}{l}\text { Assets amount } \\
\text { missing dummy }\end{array}$ & $\begin{array}{l}0.054 \\
{[0.119]}\end{array}$ & $\begin{array}{l}0.009 \\
{[0.093]}\end{array}$ & $\begin{array}{l}-0.049 \\
{[0.149]}\end{array}$ & $\begin{array}{l}-0.055 \\
{[0.042]}\end{array}$ \\
\hline Mean of dependent var. & 0.57 & 0.15 & 0.62 & 0.07 \\
\hline Pseudo-R² & 0.14 & 0.11 & 0.08 & 0.24 \\
\hline Observations & 165 & 163 & 491 & 376 \\
\hline
\end{tabular}

Notes: The table reports marginal effects, with robust standard errors in brackets. The dependent variable of the regression models is: (1) a dummy for not knowing the interest rate on credit card debt, (2) a dummy for respondents that indicate having difficulty paying off their credit card debt on time, (3) the number of credit cards the respondent has, (4) a dummy for having debt, and (5) a dummy equal to one if the amount of debt is larger than annual income. Results in Column (1), (2), (4) and (5) use probit regression models, and Column (3) is based on a negative binomial count data regression model. In Column (1) and (2) the sample is limited to respondents with credit cards only. The sample in Column (5) excludes respondents who did not provide the amount of debt (missing). The row "Mean of dependent var." displays the sample mean of the dependent variable to facilitate the interpretation of marginal effect sizes. ${ }^{* * *},{ }^{* *}$ and $*$ denote significance at the $1 \%, 5 \%$ and $10 \%$ levels, respectively. 
Table 8: Instrumental Variable Regressions

\begin{tabular}{|c|c|c|c|c|}
\hline & (1) & $(2)$ & (3) & (4) \\
\hline & $\begin{array}{l}\text { Assets other than } \\
\text { savings account }\end{array}$ & Fixed deposits & Stocks & Insurance \\
\hline \multirow[t]{2}{*}{ Financial literacy: original } & $0.078 * * *$ & $0.064^{* * *}$ & 0.009 & $-0.032 * *$ \\
\hline & {$[0.02]$} & {$[0.02]$} & {$[0.01]$} & {$[0.02]$} \\
\hline \multirow[t]{2}{*}{ Financial literacy: instrumented } & $0.171^{* *}$ & $0.225^{* * *}$ & -0.022 & $-0.217 * * *$ \\
\hline & {$[0.07]$} & {$[0.05]$} & {$[0.04]$} & {$[0.04]$} \\
\hline Instrument set & $\begin{array}{l}\text { encourage saving } \\
\text { bank before } 18\end{array}$ & $\begin{array}{l}\text { encourage saving } \\
\text { bank before } 18\end{array}$ & $\begin{array}{l}\text { encourage saving } \\
\text { bank before } 18\end{array}$ & $\begin{array}{l}\text { encourage saving } \\
\text { bank before } 18\end{array}$ \\
\hline F-test for weak instruments & $14.91^{\mathrm{a}}$ & $14.75^{\mathrm{a}}$ & $14.79^{\mathrm{a}}$ & $14.75^{\mathrm{a}}$ \\
\hline Overidentification test (Hansen J) & 1.35 & 0.123 & 0.187 & 0.016 \\
\hline Wald exogeneity test (chi-square) & 1.27 & $4.62 * *$ & 0.54 & $13.43^{* * *}$ \\
\hline $\mathrm{N}$ & 466 & 470 & 468 & 470 \\
\hline
\end{tabular}

\section{Panel B: Borrowing}

\begin{tabular}{|c|c|c|c|c|}
\hline & $\begin{array}{l}1) \\
\text { Does not now } \\
\text { interest rate on } \\
\text { credit card }\end{array}$ & $\begin{array}{l}\text { (2) } \\
\text { Has difficulty } \\
\text { paying off credit } \\
\text { card }\end{array}$ & $\begin{array}{l}\text { (3) } \\
\text { Number of credit } \\
\text { cards }\end{array}$ & $\begin{array}{l}\text { (4) } \\
\text { Debt larger than } \\
\text { annual income }\end{array}$ \\
\hline Financial literacy: original & $\begin{array}{l}-0.125^{* * *} \\
{[0.04]}\end{array}$ & $\begin{array}{l}-0.063^{* *} \\
{[0.03]}\end{array}$ & $\begin{array}{l}0.043 \\
{[0.06]}\end{array}$ & $\begin{array}{l}-0.015 \\
{[0.01]}\end{array}$ \\
\hline Financial literacy: instrumented & $\begin{array}{l}-0.211^{* *} \\
{[0.10]}\end{array}$ & $\begin{array}{l}-0.219 * * * \\
{[0.07]}\end{array}$ & $\begin{array}{l}0.584 \\
{[0.41]}\end{array}$ & $\begin{array}{l}0.031 \\
{[0.09]}\end{array}$ \\
\hline Instrument set & $\begin{array}{l}\text { fin.und. parents } \\
\text { bank before } 18\end{array}$ & $\begin{array}{l}\text { fin.und. parents } \\
\text { bank before } 18\end{array}$ & encourage saving & encourage saving \\
\hline F-test for weak instruments & $9.29^{b}$ & $9.52^{\mathrm{b}}$ & $15.56^{\mathrm{a}}$ & $11.36^{\mathrm{a}}$ \\
\hline Overidentification test (Hansen J) & 0.04 & 0.04 & --- & --- \\
\hline Wald exogeneity test (chi-square) & 0.55 & $4.21 * *$ & 2.02 & 0.26 \\
\hline $\mathrm{N}$ & 155 & 153 & 477 & 366 \\
\hline
\end{tabular}

Notes: The table reports instrumental variable (IV) probit estimation results with robust standard errors in brackets; for the number of assets owned and the number of credit cards owned the model is IV Poisson (estimated with GMM). The financial literacy measure is instrumented. The table reports the marginal effect estimate of financial literacy in the $2^{\text {nd }}$ stage regression. A full set of control variables is included, but coefficients not shown to save space. Superscript ${ }^{\mathrm{a}}$, b denotes passing the Stock-Yogo test for weak instruments at $15 \%$ and $25 \%$ maximal IV size, respectively. ${ }^{* * *},{ }^{* *}$ and $*$ denote significance at the $1 \%, 5 \%$ and $10 \%$ levels, respectively. 
Figure 1: Stock and Bond Market Participation by Amount of Financial Assets

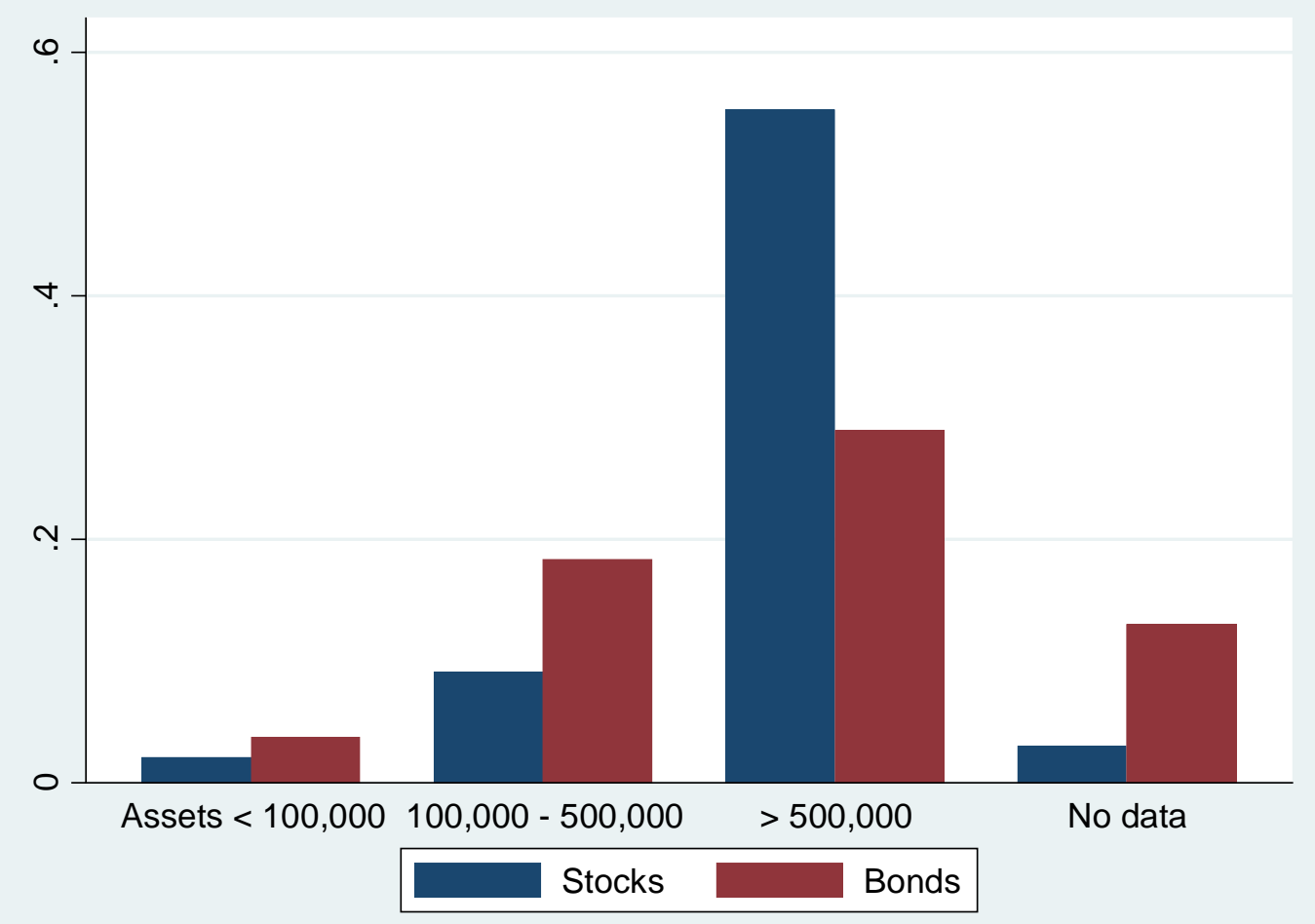




\title{
ONLINE APPENDIX
}

\section{Of}

\section{Financial Literacy and Financial Behaviour: Evidence from the Emerging Asian Middle Class}

\author{
Antonia Grohmann
}

This version: November 18, 2017

The online appendix provides additional tables with: i) information on the full sample of respondents, ii) correlations among the main variables, iii) regressions explaining financial literacy with individual characteristics, and iv) several robustness tests for the main results, explaining saving and borrowing behavior with financial literacy and a full set of controls.

\section{List of tables:}

Table A1: Mean of Key Variables for Samples based on Different Middle Class Definitions Table A2: Correlations among Main Variables

Table A3: Financial Literacy and Individual Characteristics

Table A4: Robustness of Main Results: Different Measures of Financial Literacy

Table A5: Robustness of Main Results: Different Definition of Middle Class 


\section{Table A1: Mean of Key Variables for Samples based on Different Middle Class Definitions}

\begin{tabular}{|c|c|c|c|c|c|c|}
\hline & \multirow[b]{2}{*}{ (1) All } & \multicolumn{3}{|c|}{ Middle class definition 1} & \multicolumn{2}{|c|}{ Middle class definition 2} \\
\hline & & (2) Poor & (3) Middle & (4) Rich & (5) Middle & (6) Rich \\
\hline \multicolumn{7}{|l|}{ Household income and composition } \\
\hline Personal income & 26,794 & 17,890 & 26,467 & 80,250 & 23,835 & 74,613 \\
\hline Household income & 63,908 & 33,500 & 58,457 & 512,500 & 51,283 & 267,903 \\
\hline Number of children in $\mathrm{HH}$ & 0.83 & 2.13 & 0.75 & 0.50 & 0.82 & 0.84 \\
\hline Number of adults in $\mathrm{HH}$ & 2.97 & 4.87 & 2.86 & 2.63 & 2.95 & 3.29 \\
\hline Avg. daily income per $\mathrm{HH}$ member & 32.76 & 8.15 & 28.99 & 356.16 & 25.86 & 144.18 \\
\hline $\begin{array}{l}\text { Avg. daily income per weighted } \mathrm{HH} \\
\text { member (using OECD-modified scale) }\end{array}$ & 49.84 & 15.65 & 44.61 & 499.27 & 39.48 & 217.34 \\
\hline Financial assets low (<100,000 baht) & $50 \%$ & $77 \%$ & $49 \%$ & $13 \%$ & $53 \%$ & $13 \%$ \\
\hline Financial assets high ( $>500,000$ baht) & $9 \%$ & $3 \%$ & $8 \%$ & $88 \%$ & $6 \%$ & $58 \%$ \\
\hline \multicolumn{7}{|l|}{ Fin. literacy, numeracy and risk aversion } \\
\hline Financial literacy (score out of 4) & 2.21 & 1.77 & 2.24 & 1.91 & 2.20 & 2.48 \\
\hline Numeracy (score out of 4) & 3.56 & 3.10 & 3.59 & 3.63 & 3.55 & 3.71 \\
\hline Risk aversion (scale: 0 to 1 ) & 0.46 & 0.63 & 0.45 & 0.46 & 0.46 & 0.42 \\
\hline \multicolumn{7}{|l|}{ Assets } \\
\hline Owns assets other than a savings account & $52 \%$ & $17 \%$ & $53 \%$ & $88 \%$ & $49 \%$ & $87 \%$ \\
\hline Owns fixed deposit accounts & $40 \%$ & $3 \%$ & $42 \%$ & $75 \%$ & $38 \%$ & $74 \%$ \\
\hline Owns stocks or equity mutual funds & $8 \%$ & $3 \%$ & $8 \%$ & $50 \%$ & $6 \%$ & $39 \%$ \\
\hline Owns life insurance & $16 \%$ & $7 \%$ & $16 \%$ & $50 \%$ & $15 \%$ & $35 \%$ \\
\hline Number of asset types owned & 0.75 & 0.33 & 0.75 & 2.38 & 0.66 & 2.13 \\
\hline \multicolumn{7}{|l|}{ Borrowing } \\
\hline Has at least one credit card & $33 \%$ & $13 \%$ & $34 \%$ & $38 \%$ & $31 \%$ & $58 \%$ \\
\hline Finds it difficult to pay off credit card debt & $15 \%$ & $0 \%$ & $15 \%$ & $33 \%$ & $14 \%$ & $17 \%$ \\
\hline Does NOT know interest on credit card debt & $57 \%$ & $50 \%$ & $57 \%$ & $67 \%$ & $56 \%$ & $61 \%$ \\
\hline Has any debt & $47 \%$ & $60 \%$ & $47 \%$ & $38 \%$ & $48 \%$ & $31 \%$ \\
\hline Has debt larger than annual income & $8 \%$ & $10 \%$ & $7 \%$ & $13 \%$ & $8 \%$ & $7 \%$ \\
\hline Number of respondents & 529 & 30 & 491 & 8 & 497 & 31 \\
\hline
\end{tabular}

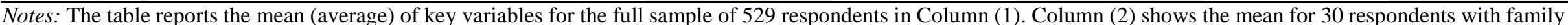

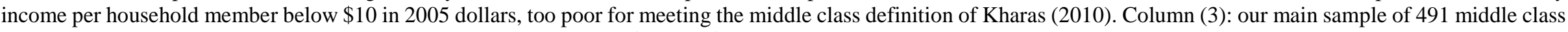

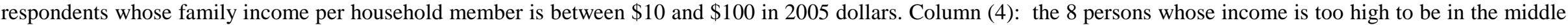

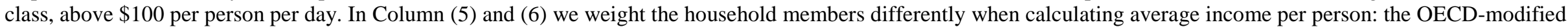

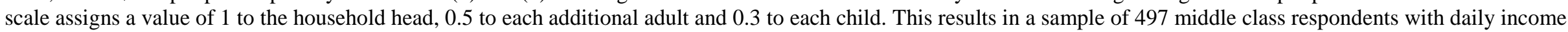
per person between $\$ 10$ and \$100 in Column (5), 31 respondents who are too rich (> \$100 per day) in Column (6), and 1 too poor (not shown). 
Online Appendix of Financial Literacy and Financial Behavior: Evidence from Emerging Asian Middle Class

Table A2: Correlations among Main Variables

\begin{tabular}{|c|c|c|c|c|c|c|c|c|c|c|c|c|c|c|c|c|c|c|c|c|}
\hline & $(1)$ & $(2)$ & (3) & (4) & (5) & $(6)$ & $(7)$ & (8) & (9) & $(10)$ & $(11)$ & $(12)$ & $(13)$ & $(14)$ & $(15)$ & $(16)$ & $(17)$ & $(18)$ & (19) & $(20)$ \\
\hline (1) Financial literacy & 1.00 & & & & & & & & & & & & & & & & & & & \\
\hline (2) Numeracy & 0.23 & 1.00 & & & & & & & & & & & & & & & & & & \\
\hline (3) Risk aversion & -0.37 & -0.25 & 1.00 & & & & & & & & & & & & & & & & & \\
\hline (4) Higher education & 0.18 & 0.15 & -0.16 & 1.00 & & & & & & & & & & & & & & & & \\
\hline (5) Female & 0.02 & 0.02 & 0.09 & -0.01 & 1.00 & & & & & & & & & & & & & & & \\
\hline (6) Age & -0.03 & -0.16 & 0.05 & -0.07 & -0.02 & 1.00 & & & & & & & & & & & & & & \\
\hline (7) Number of adults in household & -0.04 & 0.02 & 0.04 & -0.11 & -0.01 & 0.00 & 1.000 & & & & & & & & & & & & & \\
\hline (8) Log of personal income & 0.23 & 0.08 & -0.11 & 0.12 & -0.09 & 0.57 & 0.07 & 1.00 & & & & & & & & & & & & \\
\hline (9) Assets low dummy & 0.00 & 0.04 & -0.00 & -0.02 & 0.07 & -0.35 & 0.02 & -0.42 & 1.00 & & & & & & & & & & & \\
\hline (10) Assets high dummy & 0.09 & 0.01 & 0.03 & 0.06 & -0.03 & 0.33 & 0.02 & 0.50 & -0.29 & 1.00 & & & & & & & & & & \\
\hline (11) Assets other than savings & -0.28 & -0.15 & 0.15 & -0.22 & -0.05 & -0.29 & -0.01 & -0.43 & 0.25 & -0.23 & 1.00 & & & & & & & & & \\
\hline (12) Has fixed deposit account & 0.24 & 0.11 & -0.16 & 0.18 & 0.07 & 0.27 & 0.00 & 0.37 & -0.24 & 0.15 & -0.80 & 1.00 & & & & & & & & \\
\hline (13) Owns stocks & 0.10 & -0.04 & 0.03 & 0.12 & -0.07 & 0.28 & 0.07 & 0.42 & -0.22 & 0.51 & -0.28 & 0.15 & 1.00 & & & & & & & \\
\hline (14) Owns life insurance & -0.12 & -0.26 & 0.22 & 0.09 & 0.01 & 0.22 & 0.07 & 0.25 & -0.31 & 0.37 & -0.03 & 0.00 & 0.11 & 1.00 & & & & & & \\
\hline (15) Number of asset types & 0.25 & 0.10 & -0.10 & 0.20 & 0.04 & 0.41 & 0.04 & 0.63 & -0.37 & 0.44 & -0.80 & 0.70 & 0.57 & 0.20 & 1.00 & & & & & \\
\hline (16) Number of credit cards (c.c.) & 0.12 & 0.07 & -0.10 & 0.13 & 0.01 & 0.22 & 0.07 & 0.35 & -0.16 & 0.29 & -0.23 & 0.15 & 0.25 & 0.13 & 0.33 & 1.00 & & & & \\
\hline (17) Does not know interest on c.c. & -0.28 & -0.07 & 0.17 & -0.14 & 0.14 & -0.01 & 0.12 & -0.12 & -0.03 & 0.11 & 0.09 & -0.06 & -0.02 & 0.05 & 0.01 & 0.00 & 1.00 & & & \\
\hline (18) Has difficulty paying c.c. & -0.18 & -0.09 & 0.05 & -0.09 & -0.17 & -0.04 & 0.02 & -0.00 & -0.03 & -0.01 & 0.15 & -0.06 & -0.12 & 0.05 & -0.15 & -0.04 & 0.02 & 1.00 & & \\
\hline (19) Has debt & -0.03 & -0.01 & 0.01 & 0.05 & 0.00 & 0.05 & -0.09 & -0.05 & -0.02 & -0.00 & -0.03 & -0.04 & 0.04 & 0.06 & 0.02 & 0.29 & -0.06 & 0.05 & 1.00 & \\
\hline (20) Has debt > annual income & -0.01 & -0.10 & -0.07 & 0.02 & -0.09 & 0.15 & -0.10 & 0.11 & -0.17 & 0.23 & -0.10 & 0.03 & 0.19 & 0.23 & 0.20 & 0.20 & -0.19 & 0.23 & 0.38 & 1.00 \\
\hline
\end{tabular}

Notes: The table reports pairwise Pearson correlation coefficients between the main variables. The sample is limited to 491 middle class respondents whose family income per household member is between $\$ 10$ and \$100 in 2005 dollars (at PPP). 
Table A3: Financial Literacy and Individual Characteristics

\begin{tabular}{|c|c|c|c|c|}
\hline & (1) & (2) & (3) & (4) \\
\hline & Lusardi and & Financial & Financial & Financial \\
\hline & Mitchell & Literacy & Literacy & Literacy \\
\hline \multirow[t]{2}{*}{ Numeracy } & $0.134 * * *$ & $0.135 * * *$ & $0.101^{* *}$ & $0.134 * * *$ \\
\hline & {$[0.043]$} & {$[0.047]$} & {$[0.049]$} & {$[0.046]$} \\
\hline \multirow[t]{2}{*}{ Risk aversion } & $-0.887 * * *$ & $-1.333^{* * *}$ & $-1.220 * * *$ & $-1.252 * * *$ \\
\hline & {$[0.180]$} & {$[0.199]$} & {$[0.194]$} & {$[0.196]$} \\
\hline \multirow[t]{2}{*}{ Higher education } & 0.042 & 0.141 & 0.104 & 0.088 \\
\hline & [0.085] & {$[0.092]$} & [0.093] & [0.094] \\
\hline \multirow[t]{2}{*}{ Female } & 0.081 & 0.131 & 0.111 & $0.142 *$ \\
\hline & {$[0.073]$} & {$[0.081]$} & {$[0.080]$} & {$[0.082]$} \\
\hline \multirow[t]{2}{*}{ Age } & -0.011 & -0.020 & -0.010 & -0.015 \\
\hline & {$[0.031]$} & {$[0.035]$} & {$[0.036]$} & {$[0.036]$} \\
\hline \multirow[t]{2}{*}{ Age squared } & -0.008 & 0.005 & -0.005 & 0.007 \\
\hline & [0.042] & [0.047] & [0.048] & {$[0.048]$} \\
\hline \multirow[t]{2}{*}{ Number of children in $\mathrm{HH}$} & -0.021 & -0.010 & -0.011 & -0.009 \\
\hline & {$[0.040]$} & {$[0.045]$} & [0.045] & {$[0.045]$} \\
\hline \multirow[t]{2}{*}{ Number of adults in $\mathrm{HH}$} & -0.036 & -0.040 & $-0.049 *$ & -0.046 \\
\hline & {$[0.027]$} & [0.029] & {$[0.028]$} & [0.029] \\
\hline \multirow[t]{2}{*}{ Log of income } & $0.511^{* * *}$ & $0.566^{* * *}$ & $0.534 * * *$ & $0.537 * * *$ \\
\hline & {$[0.114]$} & {$[0.122]$} & {$[0.118]$} & {$[0.125]$} \\
\hline \multirow[t]{2}{*}{ Assets low dummy } & -0.081 & -0.066 & -0.052 & -0.107 \\
\hline & [0.105] & {$[0.116]$} & [0.113] & {$[0.116]$} \\
\hline \multirow[t]{2}{*}{ Assets high dummy } & 0.044 & -0.080 & 0.109 & -0.043 \\
\hline & [0.181] & [0.183] & [0.186] & {$[0.180]$} \\
\hline \multirow[t]{2}{*}{ Assets missing dummy } & $-0.305^{* *}$ & $-0.402^{* * *}$ & $-0.369 * * *$ & $-0.479 * * *$ \\
\hline & {$[0.122]$} & {$[0.131]$} & [0.132] & {$[0.134]$} \\
\hline \multirow[t]{2}{*}{ Bank account before 18} & & & $-0.347 * * *$ & \\
\hline & & & {$[0.084]$} & \\
\hline \multirow[t]{2}{*}{ Parents encouraged saving } & & & $0.569 * * *$ & $0.461 * * *$ \\
\hline & & & [0.129] & {$[0.124]$} \\
\hline $\mathrm{R}^{2}$ & 0.19 & 0.24 & 0.29 & 0.28 \\
\hline F-statistic regression & $13.57 * * *$ & $10.29 * * *$ & $16.52 * * *$ & $17.28 * * *$ \\
\hline F-test for instruments & - & - & $14.91^{* * *}$ & $13.79 * * *$ \\
\hline Observations & 491 & 491 & 466 & 459 \\
\hline
\end{tabular}

Notes: The dependent variable of the regression models is: (1) the number of correct answers to the three standard Lusardi-Mitchell (LM) financial literacy questions on a scale from 0 to 3, and in column (2), (3) and (4) our financial literacy measure on a scale from 0 to 4 , which adds a $0-1$ score for naming foreign banks operating in Thailand to the standard LM measure. Column (3) shows the first-stage regression results from the two-stage IV-probit model, when the indicator for "owning assets other than a savings account" is the dependent variable in the 2nd stage. The instruments for financial literacy are dummies for having a bank account before the age of 18 and parents encouraged savings. Column (4) shows the first-stage regression results when the dependent variable in the 2nd stage is a dummy for having debt, with parents encouraged savings as the instrument. All estimation results are based on OLS. ***, ** and $*$ denote significance at $1 \%, 5 \%$ and $10 \%$ level, respectively. 


\section{Table A4: Robustness of Main Results: Different Measures of Financial Literacy}

Panel A: Savings and Assets

\begin{tabular}{lccccc}
\hline & $\begin{array}{c}(1) \\
\text { Assets other } \\
\text { than savings } \\
\text { account }\end{array}$ & $\begin{array}{c}(2) \\
\text { Fixed deposits }\end{array}$ & $\begin{array}{c}(3) \\
\text { Stocks }\end{array}$ & $\begin{array}{c}(4) \\
\text { Insurance }\end{array}$ & $\begin{array}{c}\text { Number of } \\
\text { asset types } \\
\text { owned }\end{array}$ \\
\hline Financial Literacy & $0.078^{* * *}$ & $0.064^{* * *}$ & 0.009 & $-0.032^{* *}$ & $0.106^{* * *}$ \\
$($ LM+banks) & {$[0.022]$} & {$[0.023]$} & {$[0.009]$} & {$[0.015]$} & {$[0.034]$} \\
Pseudo-R & 0.26 & 0.18 & 0.37 & 0.34 & 0.18 \\
Financial Literacy & $0.062^{* * *}$ & 0.036 & 0.007 & -0.021 & $0.104^{* * *}$ \\
(LM score) & {$[0.024]$} & {$[0.025]$} & {$[0.010]$} & {$[0.016]$} & {$[0.039]$} \\
Pseudo-R & 0.25 & 0.17 & 0.37 & 0.33 & 0.18 \\
Financial Literacy & $0.184^{* * *}$ & $0.167^{* * *}$ & -0.014 & -0.031 & $0.148^{* *}$ \\
$($ LM dummy) & {$[0.056]$} & {$[0.054]$} & {$[0.024]$} & {$[0.038]$} & {$[0.068]$} \\
Pseudo-R ${ }^{2}$ & 0.25 & 0.18 & 0.37 & 0.33 & 0.18 \\
Financial Literacy & $0.051^{* * *}$ & 0.028 & 0.004 & $-0.033^{* *}$ & $0.075^{* *}$ \\
$($ LM +Cole) & {$[0.019]$} & {$[0.021]$} & {$[0.007]$} & {$[0.014]$} & {$[0.034]$} \\
Pseudo-R & 0.25 & 0.17 & 0.37 & 0.34 & 0.18 \\
\hline
\end{tabular}

Panel B: Borrowing

\begin{tabular}{lccccc}
\hline & $\begin{array}{c}(1) \\
\text { Does not know } \\
\text { interest rate on } \\
\text { credit card }\end{array}$ & $\begin{array}{c}\text { Finds it } \\
\text { difficult to pay } \\
\text { off credit card }\end{array}$ & $\begin{array}{c}\text { Number of } \\
\text { credit cards }\end{array}$ & $\begin{array}{c}(4) \\
\text { Has debt }\end{array}$ & $\begin{array}{c}(5) \\
\text { Debt larger than } \\
\text { annual income }\end{array}$ \\
\hline Financial Literacy & $-0.125^{* * *}$ & $-0.063^{* *}$ & 0.043 & -0.006 & -0.015 \\
(LM+banks) & {$[0.040]$} & {$[0.032]$} & {$[0.058]$} & {$[0.026]$} & {$[0.012]$} \\
Pseudo-R & 0.14 & 0.11 & 0.08 & 0.05 & 0.24 \\
Financial Literacy & $-0.122^{* * *}$ & $-0.074^{* *}$ & 0.021 & 0.012 & -0.008 \\
(LM score) & {$[0.044]$} & {$[0.034]$} & {$[0.066]$} & {$[0.029]$} & {$[0.013]$} \\
Pseudo-R & 0.13 & 0.12 & 0.07 & 0.05 & 0.23 \\
Financial Literacy & $-0.239^{* * *}$ & -0.077 & -0.045 & -0.088 & -0.038 \\
(LM dummy) & {$[0.085]$} & {$[0.078]$} & {$[0.133]$} & {$[0.065]$} & {$[0.033]$} \\
Pseudo-R ${ }^{2}$ & 0.13 & 0.09 & 0.07 & 0.05 & 0.24 \\
Financial Literacy & $-0.112^{* * *}$ & $-0.054^{*}$ & 0.072 & 0.016 & -0.012 \\
(LM +Cole) & {$[0.037]$} & {$[0.028]$} & {$[0.055]$} & {$[0.024]$} & {$[0.010]$} \\
Pseudo-R ${ }^{2}$ & 0.13 & 0.11 & 0.08 & 0.05 & 0.23
\end{tabular}

Notes: The table reports regression results for savings and borrow behavior similar to Table 6 and Table 7 in the paper, but using different measures of financial literacy, as a robustness check. A full set of control variables is included, but not shown here. The table shows marginal effects from probit and count data models, with robust standard errors in brackets. ${ }^{* *},{ }^{* *}$ and $*$ denote significance at the $1 \%, 5 \%$ and $10 \%$ levels, respectively. 
Table A5: Robustness of Main Results: Different Definition of Middle Class

Panel A. Savings and Assets

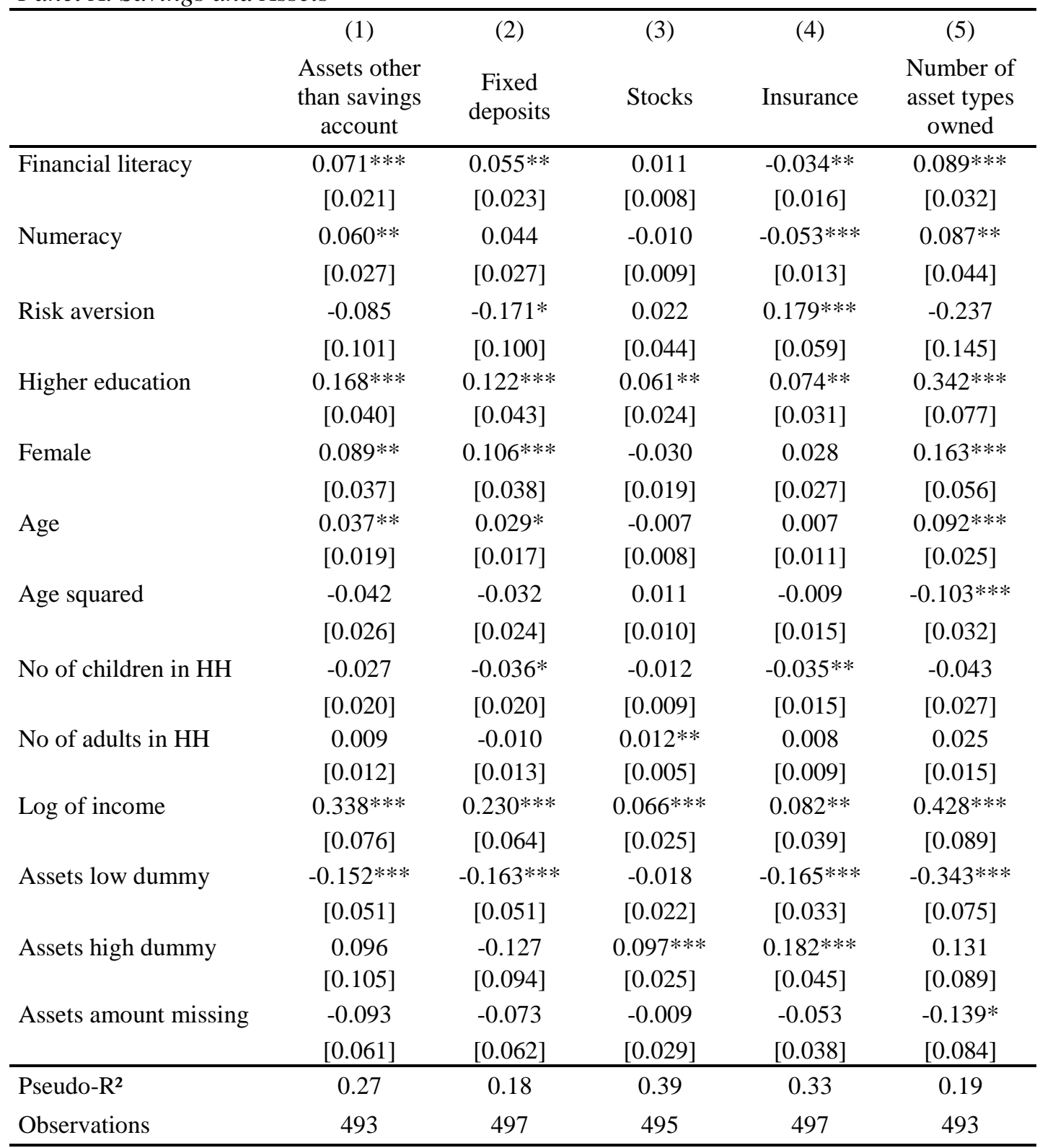

Notes: The table reports regression results for savings behavior, similar to Table 6 in the paper, but with a different definition of household income per person to determine the sample of middle class respondents (average income between 10 and 100 USD per person per day). The OECD-modified scale is used to estimate average income per weighted household member: this scale assigns a value of 1 to the household head, 0.5 to each additional adult and 0.3 to each child. ***, ** and * denote significance. 


\begin{tabular}{|c|c|c|c|c|c|}
\hline & (1) & (2) & (3) & (4) & (5) \\
\hline & $\begin{array}{l}\text { Does not } \\
\text { know } \\
\text { interest rate } \\
\text { on credit } \\
\text { card } \\
\end{array}$ & $\begin{array}{c}\text { Has } \\
\text { difficulty } \\
\text { paying off } \\
\text { credit card }\end{array}$ & $\begin{array}{l}\text { Number of } \\
\text { credit cards }\end{array}$ & Has debt & $\begin{array}{l}\text { Debt larger } \\
\text { than annual } \\
\text { income }\end{array}$ \\
\hline \multirow[t]{2}{*}{ Financial literacy } & $-0.118 * * *$ & $-0.061^{*}$ & 0.041 & 0.019 & -0.000 \\
\hline & [0.043] & {$[0.033]$} & {$[0.056]$} & {$[0.026]$} & [0.015] \\
\hline \multirow[t]{2}{*}{ Numeracy } & -0.003 & -0.056 & $0.118^{*}$ & -0.007 & $-0.029 * *$ \\
\hline & {$[0.070]$} & {$[0.044]$} & {$[0.068]$} & {$[0.027]$} & [0.013] \\
\hline \multirow[t]{2}{*}{ Risk aversion } & -0.051 & 0.051 & -0.378 & 0.038 & $-0.141^{* *}$ \\
\hline & {$[0.203]$} & {$[0.130]$} & {$[0.265]$} & {$[0.110]$} & {$[0.056]$} \\
\hline \multirow[t]{2}{*}{ Higher education } & -0.122 & -0.065 & $0.289 * *$ & 0.058 & 0.016 \\
\hline & {$[0.093]$} & {$[0.058]$} & {$[0.128]$} & {$[0.051]$} & {$[0.030]$} \\
\hline \multirow[t]{2}{*}{ Female } & 0.089 & $-0.100 *$ & 0.088 & -0.008 & -0.029 \\
\hline & {$[0.079]$} & {$[0.057]$} & {$[0.101]$} & {$[0.045]$} & {$[0.025]$} \\
\hline \multirow[t]{2}{*}{ Age } & -0.026 & -0.027 & $0.116^{* *}$ & $0.088 * * *$ & $0.030^{* *}$ \\
\hline & {$[0.039]$} & {$[0.027]$} & {$[0.046]$} & [0.019] & {$[0.013]$} \\
\hline \multirow[t]{2}{*}{ Age squared } & 0.033 & 0.029 & $-0.147 * *$ & $-0.111^{* * *}$ & $-0.036^{* *}$ \\
\hline & {$[0.051]$} & {$[0.037]$} & {$[0.060]$} & {$[0.026]$} & [0.017] \\
\hline \multirow[t]{2}{*}{ No of children in $\mathrm{HH}$} & 0.010 & 0.039 & 0.070 & 0.006 & 0.009 \\
\hline & {$[0.040]$} & {$[0.027]$} & {$[0.062]$} & {$[0.024]$} & {$[0.013]$} \\
\hline \multirow[t]{2}{*}{ No of adults in $\mathrm{HH}$} & $0.044^{*}$ & -0.017 & 0.013 & -0.003 & -0.006 \\
\hline & {$[0.027]$} & {$[0.016]$} & {$[0.034]$} & {$[0.015]$} & {$[0.010]$} \\
\hline \multirow[t]{2}{*}{ Log of income } & $-0.211 *$ & 0.100 & $0.523 * * *$ & $-0.142 *$ & -0.022 \\
\hline & {$[0.123]$} & {$[0.080]$} & {$[0.180]$} & {$[0.079]$} & {$[0.041]$} \\
\hline \multirow[t]{2}{*}{ Assets low dummy } & -0.066 & 0.006 & -0.014 & -0.006 & $-0.056^{*}$ \\
\hline & {$[0.107]$} & {$[0.079]$} & {$[0.147]$} & {$[0.065]$} & {$[0.032]$} \\
\hline \multirow[t]{2}{*}{ Assets high dummy } & 0.199 & -0.026 & $0.396 * *$ & 0.111 & $0.115^{* * *}$ \\
\hline & {$[0.130]$} & {$[0.093]$} & {$[0.172]$} & {$[0.111]$} & {$[0.038]$} \\
\hline Assets amount & 0.017 & 0.035 & 0.031 & 0.033 & -0.031 \\
\hline missing & {$[0.126]$} & {$[0.095]$} & {$[0.150]$} & {$[0.074]$} & {$[0.041]$} \\
\hline Pseudo-R² & 0.11 & 0.12 & 0.08 & 0.04 & 0.21 \\
\hline Observations & 154 & 152 & 497 & 481 & 385 \\
\hline
\end{tabular}

Notes: The table reports regression results for borrowing behavior, similar to Table 7 in the paper, but with a different definition of household income per person to determine the sample of middle class respondents (average income between 10 and 100 USD per person per day). The OECD-modified scale is used to estimate average income per weighted household member: this scale assigns a value of 1 to the household head, 0.5 to each additional adult and 0.3 to each child. ***, ** and * denote significance at the $1 \%, 5 \%$ and $10 \%$ levels, respectively. 
Online Appendix of Financial Literacy and Financial Behavior: Evidence from Emerging Asian Middle Class 